https://helda.helsinki.fi

\title{
Enrichment of 180 in the mantle sources of the Antarctic portion of the Karoo large igneous province
}

\section{Heinonen, Jussi S.}

2018-03

Heinonen , J S , Luttinen , A V \& Whitehouse , M J 2018 , ' Enrichment of 180 in the mantle sources of the Antarctic portion of the Karoo large igneous province ' , Contributions to Mineralogy and Petrology , vol. 173 , no. 3 , 21 . https://doi.org/10.1007/s00410-018-1447-4

http://hdl.handle.net/10138/233825

https://doi.org/10.1007/s00410-018-1447-4

acceptedVersion

Downloaded from Helda, University of Helsinki institutional repository.

This is an electronic reprint of the original article.

This reprint may differ from the original in pagination and typographic detail.

Please cite the original version. 
Heinonen, J.S., Luttinen, A.V., Whitehouse, M.J., 2018. Enrichment of ${ }^{18} \mathrm{O}$ in the mantle sources of the Antarctic portion of the Karoo large igneous province. Contributions to Mineralogy and Petrology 173:21. https://doi.org/10.1007/s00410-018-1447-4 (Author's postprint)

\section{Enrichment of ${ }^{18} \mathrm{O}$ in the mantle sources of the Antarctic portion of the Karoo large igneous province}

Jussi S. Heinonen ${ }^{\mathrm{a}, \mathrm{b}}(\mathrm{PhD}$, corresponding author, jussi.s.heinonen@ helsinki.fi, +35850-3185304)

Arto V. Luttinen ${ }^{\mathrm{b}}(\mathrm{PhD}$, arto.luttinen@ helsinki.fi, +35850-5184686)

Martin J. Whitehouse ${ }^{\mathrm{c}}$ (PhD, martin.whitehouse@ nrm.se, +46-8-5195 5169)

${ }^{a}$ Department of Geosciences and Geography, P.O. Box 64, University of Helsinki, 00014, Helsinki, Finland

${ }^{\mathrm{b}}$ Finnish Museum of Natural History, P.O. Box 44, University of Helsinki, 00014, Helsinki,

Finland

${ }^{\mathrm{c}}$ Department of Geosciences, Swedish Museum of Natural History, PO Box 50 007, SE-10405

Stockholm, Sweden

\section{Abstract}

Karoo continental flood basalt (CFB) province is known for its highly variable trace element and isotopic composition, often attributed to the involvement of continental lithospheric sources. Here we report oxygen isotopic compositions measured with secondary ion mass spectrometry for handpicked olivine phenocrysts from 190-180 Ma CFBs and intrusive rocks from Vestfjella, western Dronning Maud Land, that forms an Antarctic extension of the Karoo province. The Vestfjella lavas exhibit heterogeneous trace element and radiogenic isotope compositions (e.g., $\varepsilon_{\mathrm{Nd}}$ from -16 to +2 at $180 \mathrm{Ma}$ ) and the involvement of continental lithospheric mantle and/or crust in their petrogenesis has previously been suggested. Importantly, our sample set also includes rare primitive dikes that have been derived from depleted asthenospheric mantle sources $\left(\varepsilon_{\mathrm{Nd}}\right.$ up to +8 at $180 \mathrm{Ma}$ ). The majority of the oxygen isotopic compositions of the olivines from these dike rocks $\left(\delta^{18} \mathrm{O}=4.4-5.2 \%\right.$; Fo $\left.=78-92 \mathrm{~mol} . \%\right)$ are also compatible with such sources. The olivine phenocrysts in the lavas, however, are characterized by notably higher $\delta^{18} \mathrm{O}(6.2-7.5 \%$; Fo $=70$ $88 \mathrm{~mol} . \%)$ and one of the dike samples gives intermediate compositions (5.2-6.1\%o, Fo $=83-87$ mol. \%) between the other dikes and the CFBs. The oxygen isotopic compositions do not correlate with radiogenic isotope compositions susceptible to crustal assimilation $(\mathrm{Sr}, \mathrm{Nd}$, and $\mathrm{Pb}$ ) or with geochemical indicators of pyroxene-rich mantle sources. Instead, $\delta^{18} \mathrm{O}$ correlates positively with enrichments in large-ion lithophile elements (especially $\mathrm{K}$ ) and ${ }^{187} \mathrm{Os}$. We suggest that the oxygen isotopic compositions of the Vestfjella CFB olivines primarily record large-scale subduction-related metasomatism of the sub-Gondwanan mantle (base of the lithosphere or deeper) prior to Karoo magmatism. The overall influence of such sources to Karoo magmatism is not known, but, in addition to continental lithosphere, they may be responsible for some of the geochemical heterogeneity observed in the CFBs.

Keywords: oxygen isotopes; continental flood basalt; large igneous province; Karoo; Antarctica; olivine; mantle; metasomatism

\section{Introduction}

Continental flood basalts (CFBs) are remnants of the largest subaerial effusive lava eruptions on Earth. Their petrogenesis and ultimate origin is challenging to study, because they are highly variable geochemically and show evidence of considerable interaction with (or even derivation from) continental lithosphere (e.g., Marsh, 1987). Just small amounts of assimilation of the parental melts with lithospheric materials enriched in incompatible trace elements can overshadow the trace element and radiogenic isotope signatures derived from sublithospheric mantle sources (e.g., Brandon et al., 1993; Hansen and Nielsen, 1999; Heinonen et al., 2016). 
Heinonen, J.S., Luttinen, A.V., Whitehouse, M.J., 2018. Enrichment of ${ }^{18} \mathrm{O}$ in the mantle sources of the Antarctic portion of the Karoo large igneous province. Contributions to Mineralogy and Petrology 173:21. https://doi.org/10.1007/s00410-018-1447-4 (Author's postprint)

Oxygen isotopes are useful in studying source composition of primitive CFBs, because potential lithospheric assimilants have similar $\mathrm{O}$ concentrations with them unlike in the case of contamination-sensitive incompatible trace elements such as $\mathrm{Sr}, \mathrm{Nd}$, and $\mathrm{Pb}$ that are enriched in the lithosphere. In other words, small amounts of mixing with external materials does not strongly effect the $\mathrm{O}$ isotopic composition of a primitive CFB magma. Furthermore, the $\mathrm{O}$ isotopic compositions of olivine phenocrysts collected from high-Mg lavas and dikes reveal information from the very early stages of CFB magma evolution: early-crystallized olivines are more likely to preserve primary melt signatures that may have been overprinted in the residual melts by subsequent differentiation processes. Importantly, significant fractionation of $\mathrm{O}$ isotopes can only take place in relatively low-temperature environments, i.e., near the surface of the Earth. Anomalous primary $\delta^{18} \mathrm{O}$ values of CFB olivine phenocrysts and/or magmas (estimated on the basis of either whole-rock or phenocryst values) relative to mid-ocean ridge basalts and mantle peridotites ( $5.5 \%$; Eiler, 2001) or mantle olivine ( $5.2 \%$; Mattey et al., 1994) have thus been linked to considerable amounts of early crustal assimilation (e.g., Peng et al., 1994; Baker et al., 2000) or entrainment of recycled crustal materials in the mantle source (e.g., Harmon and Hoefs, 1995; Harris et al., 2015; Howarth and Harris, 2017; Yu et al., 2017).

The Jurassic ( 190-180 Ma) Karoo large igneous province (LIP), related to the break-up of the Gondwana supercontinent and presently located in Africa and Antarctica (Fig. 1), is a widely known example of a CFB province that is characterized by considerable geochemical heterogeneity. For example, the initial $\varepsilon_{\mathrm{Nd}}$ values of the basalts and associated dikes span from +9 to -17 at $180 \mathrm{Ma}$ (Riley et al., 2005; Luttinen et al., 2015). Several studies have suggested an important role for the continental lithosphere in the petrogenesis of the CFBs (e.g., Duncan et al., 1984; Hawkesworth et al., 1984; Ellam and Cox, 1989; Jourdan et al., 2007; Neumann et al., 2011).

Although most of the Karoo LIP basalts represent differentiated melts, some highly magnesian magma types are also known. These include the Mwenezi and Tuli picrites in Africa which have been strongly influenced by enriched lithospheric sources (Ellam and Cox, 1989, 1991; Sweeney et al., 1991; Ellam et al., 1992; Ellam, 2006), although the involvement of a depleted mantle (DM) source has also been suggested (Ellam and Cox, 1991; Kamenetsky et al., 2017). Recently, the olivines from these picrites were found to exhibit elevated $\delta^{18} \mathrm{O}(6.0-6.7 \%)$ that has been suggested to reflect the involvement of ancient recycled eclogite sources, probably emplaced into the Gondwanan SCLM keel (Harris et al., 2015). The role of such sources in the generation of the bulk of the Karoo LIP is unknown, because the picrites are a relatively minor component of the Karoo mafic lavas.

Several highly magnesian dikes are known from the Antarctic portion of Karoo LIP: these include variably enriched magma types that have sampled various recycled components in the sublithospheric or lithospheric mantle (E-FP, Groups 3 and 4; Riley et al., 2005; Heinonen et al., 2010, 2013, 2014). These magma types or their anomalous sources have likely had very limited influence in the petrogenesis of the Karoo LIP as a whole, however, and they are not the focus of this study. The most petrogenetically significant Antarctic Karoo magma types are the relatively depleted dikes (meimechites, ferropicrites, picrites, and basalts; D-FP' ${ }^{1}$ ) derived from DM sources similar to those of modern Southwest Indian Ridge mid-ocean ridge basalts (SWIR MORBs) (Heinonen and Luttinen, 2008, 2010; Heinonen et al., 2010; Heinonen and Kurz, 2015; Luttinen et al., 2015). They do not show evidence of significant crustal assimilation and their depleted asthenospheric sources have likely provided parental melts for many of the Antarctic CFBs (Heinonen et al., 2016).

\footnotetext{
${ }^{1}$ In previous studies, the MORB-like low-Nb dikes have been considered a separate magma type from other "depleted meimechites and ferropicrites" (D-FP), although they clearly share the same mantle source (see Heinonen et al., 2010; Luttinen et al., 2015). The only major differences are caused by slightly different conditions of mantle melting. We acknowledge the complexity of the magma type classification and simplify the discussion in this paper by including all of the DM-sourced dikes under the D-FP denotation regardless of whether they had common parental magmas or not.
} 
In this study, we present olivine $\mathrm{O}$ isotope data acquired with secondary ion mass spectrometry (SIMS) for Karoo-related CFBs and D-FP dikes from Vestfjella mountain range (western Dronning Maud Land), Antarctica (Fig. 2). The causes for the apparent O isotopic and coupled large-ion lithophile element (LILE) heterogeneity in their sources and the ${ }^{18} \mathrm{O}$-enriched isotope signatures of the Vestfjella CFBs, and overall implications of these findings for the petrogenesis of the Karoo LIP, are discussed.

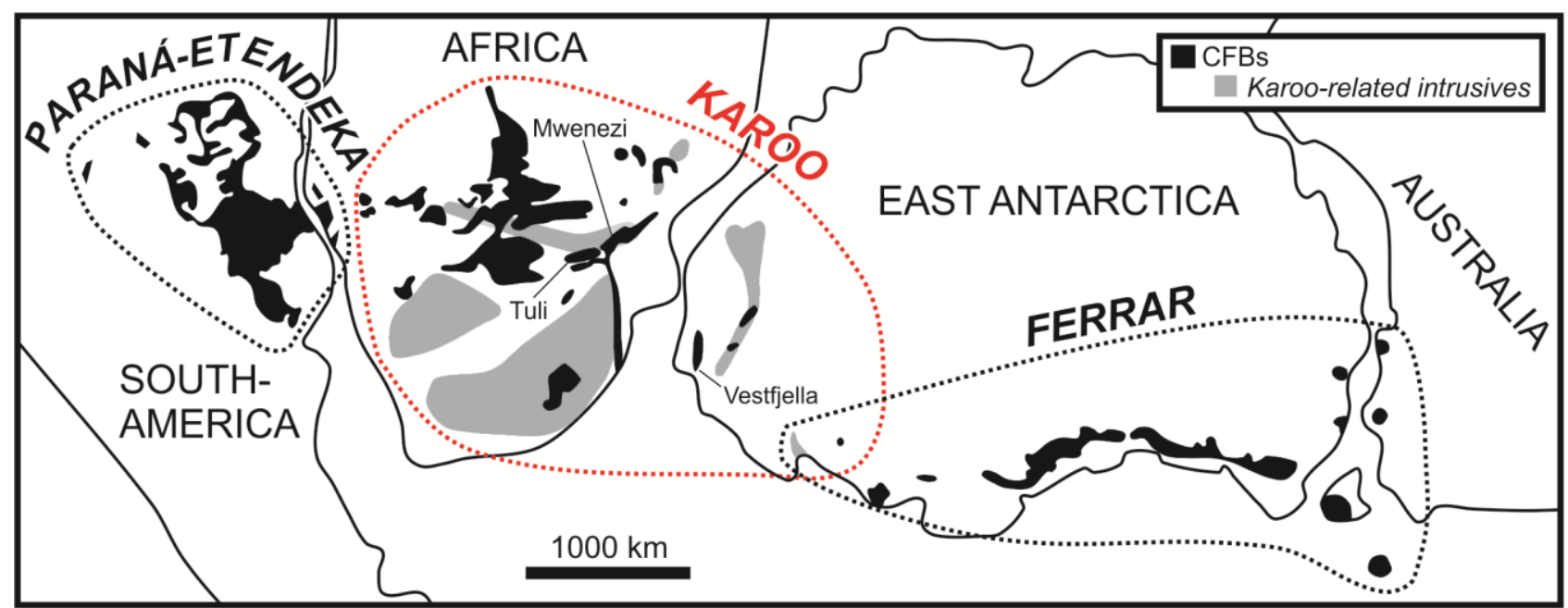

Fig. 1. A reconstruction (modified after Hergt et al., 1991; Storey et al., 1992; Segev, 2002; Leat et al., 2006; Jourdan et al., 2007) of Gondwana supercontinent showing the distribution of Mesozoic CFBs. In the case of the Karoo LIP, the extent of related intrusive rocks (found outside CFBs) is also shown.

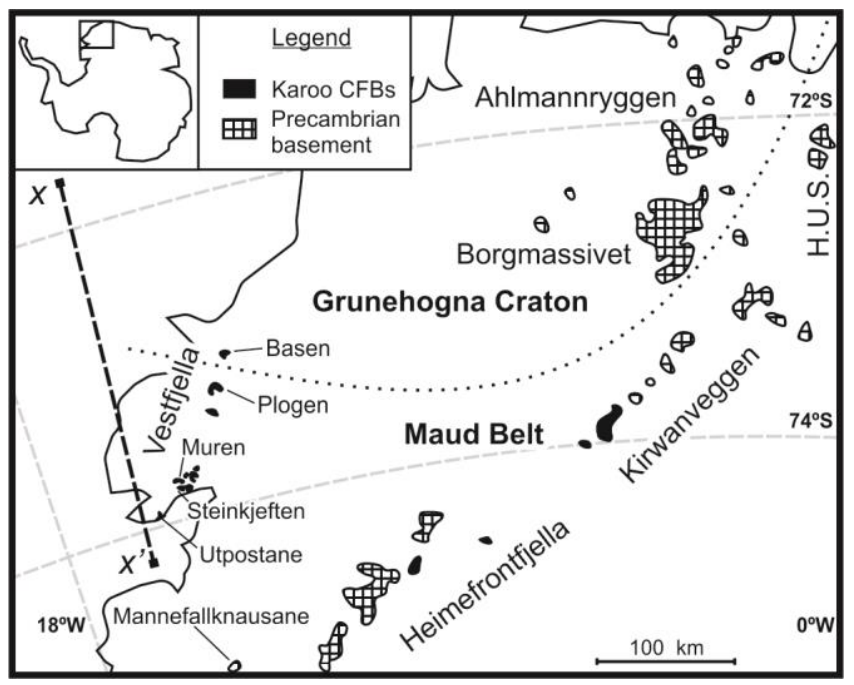

Fig. 2. Distribution of Karoo LIP CFBs in western Dronning Maud Land. Lithospheric boundary is based on a reconstruction of Corner (1994). H.U.S. = H.U. Sverdrupfjella. A schematic cross section across line segment $\mathrm{x}-\mathrm{x}^{\prime}$ is illustrated in Fig. 8.

\section{Geological background}

The $\sim 180$ Ma Karoo LIP represents one of the three major CFB provinces related to the early breakup of Gondwana supercontinent (other two being the 180 Ma Ferrar province, sometimes joined together with Karoo as the Karoo-Ferrar LIP, and the 130 Ma Paraná-Etendeka province; Fig. 1). CFBs and related intrusive rocks belonging to the Karoo LIP are found sporadically covering an area of about two million $\mathrm{km}^{2}$ in southern Africa and Dronning Maud Land in East Antarctica. 
Heinonen, J.S., Luttinen, A.V., Whitehouse, M.J., 2018. Enrichment of ${ }^{18} \mathrm{O}$ in the mantle sources of the Antarctic portion of the Karoo large igneous province. Contributions to Mineralogy and Petrology 173:21. https://doi.org/10.1007/s00410-018-1447-4 (Author's postprint)

The basement of the Karoo LIP CFBs consists of partially reworked Archean cratons surrounded by numerous Proterozoic metamorphic belts that together form the Kalahari craton (e.g., Jacobs et al., 2008). There are indications that the lithosphere beneath the central parts of the craton is still more than $200 \mathrm{~km}$ thick (e.g., Rudnick and Nyblade, 1999). In Africa, the lavas are in places overlain by Cretaceous and Phanerozoic sedimentary rocks.

\subsection{Geology of the study area}

The foundation of the Karoo-related CFBs at western Dronning Maud Land (Fig. 2) is composed of sporadic Permian fossil-rich sedimentary rocks (e.g, Lindström, 1995) and a Precambrian basement complex (e.g., Groenewald et al., 1995; Jacobs et al., 2008; Wolmarans and Kent, 1982). The Archean Grunehogna Craton, suggested to dominate the northern part of the area on the basis of geophysical studies (Fig. 2), only crops out in one location that consists of $\sim 3.1 \mathrm{Ga}$ S-type granite (Marschall et al., 2010). The craton is otherwise overlain by Mesoproterozoic metasupracrustal rocks belonging to the Ritscherflya Supergroup and $\sim 1.1$ Ga Borgmassivet mafic intrusions (e.g., Moyes et al., 1995). The Grunehogna Craton is bounded in south by the Proterozoic Maud Belt that mostly consists of highly metamorphosed supracrustal rocks (e.g., Groenewald et al., 1995). These are related to the $\sim 1.1 \mathrm{Ga}$ Grenvillian orogeny and experienced significant tectonic reworking accompanied by metamorphic and magmatic overprinting during the $\sim 0.5 \mathrm{Ga}$ PanAfrican orogeny (Jacobs et al., 1993, 1998).

Antarctic Karoo LIP CFBs and related intrusive rocks are found at least in Ahlmannryggen, Heimefrontfjella, H. U. Sverdrupfjella, Kirwanveggen, Mannefallknausane, and Vestfjella (Fig. 2). Vestfjella is a $~ 130-\mathrm{km}$-long discontinuous chain of nunataks, almost solely composed of CFBs having a stratigraphical thickness in excess of $1 \mathrm{~km}$ (Luttinen and Furnes, 2000). Together with the associated intrusive rocks, the Vestfjella CFBs form the volumetrically most important part of the Karoo CFB province exposed in Antarctica.

\subsection{Vestfjella CFBs and D-FP dikes}

The Vestfjella CFB lavas represent tholeiitic basalts and rare picrites that show significant trace element and isotopic variation (Fig. 3). In the traditional high-Ti low-Ti classification, most of the lavas are low-Ti types, whereas intrusive rocks contain several high-Ti types (Luttinen and Furnes, 2000; Luttinen et al., 2015; see Fig. 3a for magma types analyzed in this study). The lavas can be divided into four chemical types (CT) on the basis of trace element and $\mathrm{Nd}$ isotopic composition: high- $\varepsilon_{\mathrm{Nd}}$ CT1, low- $\varepsilon_{\mathrm{Nd}}$ CT1, CT2, and CT3 (Luttinen and Siivola 1997; Luttinen et al. 1998; Luttinen and Furnes 2000). The various intrusive rocks of Vestfjella include the primitive DM-sourced D-FP magma type that is found as relatively thin cross-cutting dikes throughout Vestfjella (Heinonen and Luttinen, 2008; Heinonen et al., 2010; Luttinen et al., 2015). One dike is also known from Mannefallknausane.

Recent modeling using energy-constrained assimilation-fractional crystallization equations has shown that the different CT lavas may have differentiated from DM-sourced parental melts similar to some D-FP magmas: 1-15 wt. \% assimilation of Archean crust (low- $\varepsilon_{\mathrm{Nd}} \mathrm{CT} 1$ ), Proterozoic lower crust (low- $\varepsilon_{\mathrm{Nd}}$ CT1), and various portions of SCLM (CT2 and CT3) by MORBlike parental melts can largely explain their incompatible immobile trace element and $\mathrm{Nd}$ isotopic variation (Heinonen et al., 2016). Despite having interacted with very different lithospheric materials, both CT1 and CT3 magma types show significant enrichment in many fluid-mobile LILEs (namely Rb, Ba, K, and Sr; Fig. 3d,e). Such LILE enrichment, also observed in some of the D-FP dikes (Fig. 3f), is considered to be a primary source-derived feature and is lacking from the CT2 magma type (Luttinen et al., 1998; Luttinen and Furnes, 2000). 

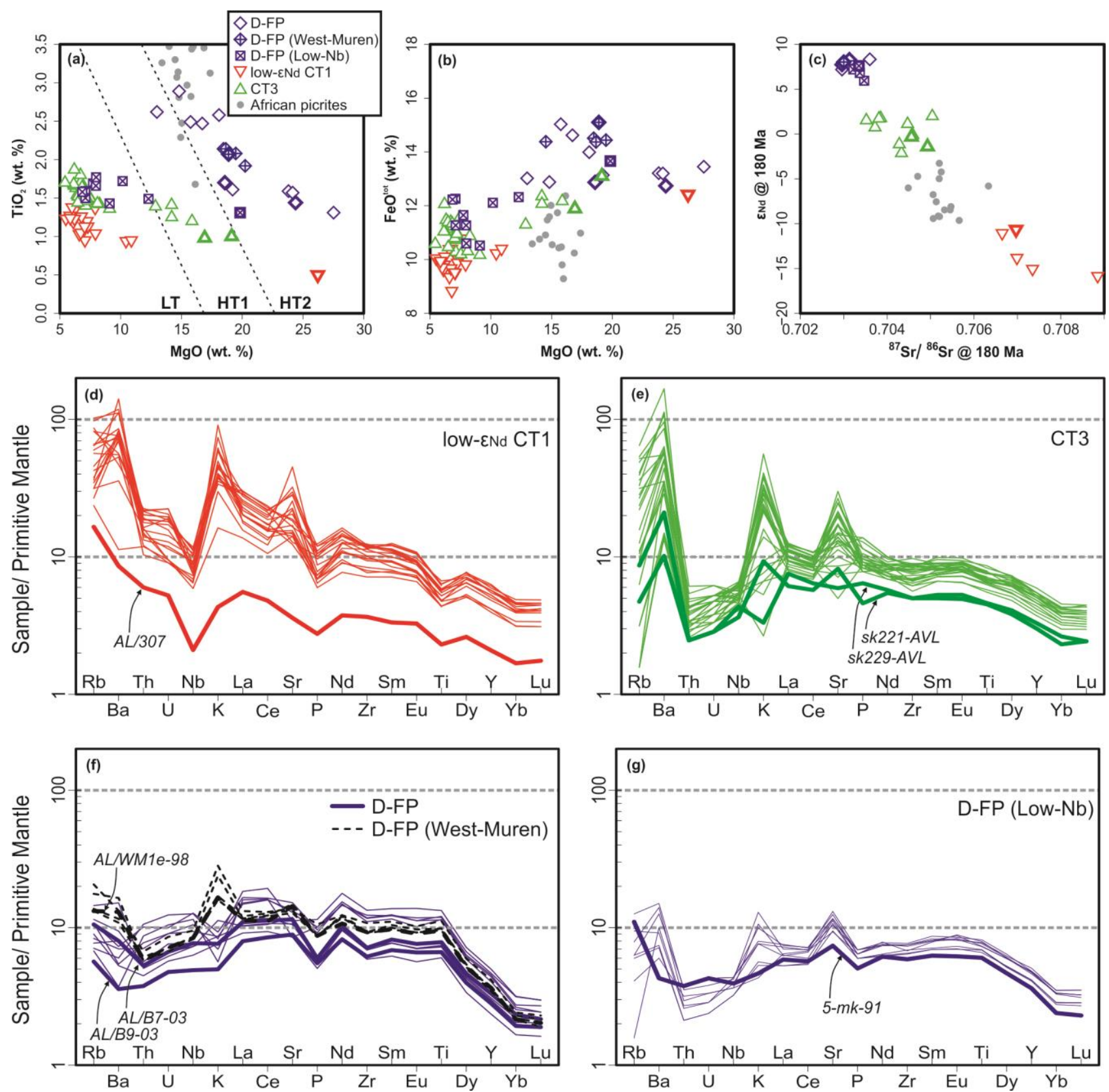

Fig. 3. Geochemical characteristics of the Karoo LIP samples and magma types considered in this study shown in a) $\mathrm{TiO}_{2}$ vs. $\mathrm{MgO}$, b) $\mathrm{FeO}^{\text {tot }}$ vs. $\mathrm{MgO}$, c) $\varepsilon_{\mathrm{Nd}}$ vs. ${ }^{87} \mathrm{Sr} /{ }^{86} \mathrm{Sr}$ at $180 \mathrm{Ma}$, and primitive-mantle-normalized trace element patterns of d) low- $\varepsilon_{\mathrm{Nd}} \mathrm{CT} 1$, e) CT3, f) normal and West-Muren D-FP, and g) Low-Nb D-FP. Major element compositions calculated 100\% volatile free. Normalization values after Sun and McDonough (1989). Samples analyzed for olivine O isotopes in this study are shown in bold. Data sources are Luttinen and Siivola (1997), Luttinen et al. (1998), Luttinen and Furnes (2000), Heinonen and Luttinen (2008), and Heinonen et al. (2010). African picrites displayed in a-c consist of Mwenezi and Tuli picrites (Ellam and Cox, 1989; Jourdan et al., 2007). In a, stippled lines separating low-Ti (LT) from high-Ti (HT1 and HT2) magma types is after Natali et al. (2017). See Online Resource 2 for complete list of Antarctic samples included in these illustrations.

\section{Samples and analytical methods}

\subsection{Samples}

Our single-grain olivine $\mathrm{O}$ isotopic analyses focused on the D-FP magma type and Vestfjella CFBs. In the case of the CFBs, we only sampled low- $\varepsilon_{\mathrm{Nd}} \mathrm{CT} 1$ and CT3 magma types, because lavas that contain fresh olivine are not known from high- $\varepsilon_{\mathrm{Nd}} \mathrm{CT} 1$ and CT2 lavas. Major element, trace 
Heinonen, J.S., Luttinen, A.V., Whitehouse, M.J., 2018. Enrichment of ${ }^{18} \mathrm{O}$ in the mantle sources of the Antarctic portion of the Karoo large igneous province. Contributions to Mineralogy and Petrology 173:21. https://doi.org/10.1007/s00410-018-1447-4 (Author's postprint)

element, mineral chemical, and $\mathrm{Sr}, \mathrm{Nd}, \mathrm{Pb}, \mathrm{Os}$, and $\mathrm{He}$ isotopic data for these rocks have been reported elsewhere (Luttinen and Furnes, 2000; Heinonen and Luttinen, 2008, 2010; Heinonen et al., 2010; Heinonen and Kurz, 2015). Some crucial major and trace element characteristics of these samples and their respective magma types are illustrated in Fig. 3.

The D-FP samples AL/B7-03, AL/B9-03, and AL/WM1e-98 are exceptionally fresh and do not exhibit any notable signs of secondary alteration or crustal contamination, and are close representatives of primary melt compositions (Heinonen and Luttinen, 2008, 2010; Heinonen et al., 2010). D-FP sample 5-mk-91, however, is a cumulate sample that has been collected close to a contact with a Proterozoic granite from Mannefallknausane (Heinonen et al., 2010). The sample from West-Muren, AL/WM1e-98, exhibits notable enrichment in LILEs (especially K) relative to other D-FP samples despite having similar $\mathrm{U}, \mathrm{Th}, \mathrm{Nb}$, and LREE concentrations - this feature is primary and is pervasively observed in all fresh samples collected from the same dike (Fig. 3f).

On the contrary, the olivine-rich samples from the Vestfjella CT lavas have rarely preserved their primary compositions and the selected samples from the low- $\varepsilon_{\mathrm{Nd}} \mathrm{CT} 1$ (AL/307) and CT3 (sk221-AVL; sk229-AVL) magma types are all from altered cumulate parts of lava flows. The hand-picked olivines from the crushed samples, however, contain pristine parts which have preserved magmatic compositions (Online Resource 1). We only analyzed transparent fresh grains and avoided serpentine-filled fractures or inclusions. In the most altered sample sk221-AVL, the olivine grains were quite small and tightly attached to other silicate and oxide minerals and the separated grains were thus polymineralic (Online Resource 1). For the purpose of whole-rock geochemical comparison in the case of the Vestfjella CT lavas, we prefer using the compositions of the unaltered non-cumulate samples of the respective magma types (Fig. 3; see Online Resource 2). Note that the relative large-ion lithophile element (LILE: $\mathrm{Rb}, \mathrm{Ba}, \mathrm{K}, \mathrm{Sr}$ ) enrichment is a characteristic feature of the low- $\varepsilon_{\mathrm{Nd}} \mathrm{CT} 1$ and CT3 magma types (Fig. 3d,e) - this characteristic has been disturbed by secondary alteration in the olivine-bearing samples (see Luttinen and Furnes, 2000). This is clearly demonstrated in the differences between the LILE patterns of the two CT3 samples analyzed in this study (Fig. 3e).

\subsection{Oxygen isotope and mineral chemical analysis}

The hand samples were crushed and the freshest olivine grains were hand-picked from sieved and magnetically separated fractions with a diameter of $0.25-1 \mathrm{~mm}$. The grains were mounted in epoxy, and polished. Optical and scanning electron microscope images of the fractions are presented in Online Resource 1. The mounts were mapped and analysis points selected using secondary electron microscopy at the Geological Survey of Finland. After adding a $30 \mathrm{~nm}$ gold coating, the oxygen isotope analyses were performed at the NordSIM laboratory, Swedish Museum of Natural History using a Cameca IMS 1280 multicollector-equipped large geometry ion microprobe. The basic instrument setup and analytical protocols closely follow those described by Heinonen et al. (2015a) for zircon, staying well within limits on in-run beam centering in the field aperture described by Whitehouse and Nemchin (2009). All data were normalized to regular measurements of the San Carlos olivine that bracketed every six unknown analyses, assuming a $\delta^{18} \mathrm{O}_{\text {V-SMOw }}$ of $5.30 \%$, similar to recent measurements using $\mathrm{CO}_{2}$-laser $\mathrm{BrF}_{5}$ fluorination techniques of $5.28 \pm 0.04 \%$ \% $(1 \sigma)$ by Kusakabe \& Matsuhisa (2008) and $5.27 \pm 0.04 \%$ \%o $(2 \sigma)$ by Ahn et al. (2012). Several studies have reported that different batches of "San Carlos olivine" are not necessarily homogeneous (e.g., Thirlwall et al., 2006; Starkey et al., 2016) and laser fluorination analysis of single grains from the batches available at NordSIM have yielded values ranging from $5.12 \pm 0.07$ to $5.46 \pm 0.03 \%$ o $(n=4$, average $5.3 \pm 0.4 \%(2 \sigma)$; C. Harris, University of Cape Town, pers. comm.). Since this range is likely to be batch related, any deviation will impose a systematic bias of $< \pm 0.2 \%$ rather than a random error component and for this reason, we have plotted our data using the analytical session uncertainties without propagating this additional uncertainty. 
Heinonen, J.S., Luttinen, A.V., Whitehouse, M.J., 2018. Enrichment of ${ }^{18} \mathrm{O}$ in the mantle sources of the Antarctic portion of the Karoo large igneous province. Contributions to Mineralogy and Petrology 173:21. https://doi.org/10.1007/s00410-018-1447-4 (Author's postprint)

Minor drift corrections $(<3 \mathrm{ppm} / \mathrm{run})$ were applied to the data sets where applicable based on minimizing the session external uncertainty on the standards ( $n=74$ over three sessions), which was $\pm 0.34 \%(2 \sigma)$. This value is propagated in quadrature with the generally much smaller $(<0.1$ \%o s.e. mean) within run uncertainty. The olivines studied here range from Fo70 to Fo92, which is within the range shown recently by Isa et al. (2017) to be not significantly affected by compositionally dependent instrumental mass bias. Complete data of the olivines analyzed in this study and standard runs are presented in Online Resource 3.

Olivine major and minor element compositions were determined at the Department of Geosciences and Geography, University of Helsinki, with a JEOL JXA-8600 electon probe microanalyzer (EPMA) equipped with four wavelength-dispersive spectrometers. The analysis spots were selected as close to the SIMS spots as possible. The details as well as precision and accuracy of the method has been described by Heinonen and Fusswinkel (2017), who utilized the same olivine mounts that were used in this study.

\section{Results}

The results of our $\mathrm{O}$ isotope and mineral chemical analyses of olivines are presented in Table 1 and illustrated in Fig. 4a. For comparison with other trace element and isotope compositions acquired from whole-rock samples, we use calculated melt $\delta^{18} \mathrm{O}$ values (Fig. 4b): these are discussed in detail in section 5. We acknowledge that the precision of our analyses does not match that obtainable by modern laser fluorination techniques, but it is still enough to validate the significant variation shown by the current data.

All analyzed olivine grains have high $\mathrm{CaO}$ contents (> 0.19 wt.\%; Table 1) indicating that they are phenocrysts and not mantle xenocrysts (see Simkin and Smith, 1970; Heinonen and Luttinen, 2010). D-FP sample AL/B7-03 olivines exhibit fairly low $\delta^{18} \mathrm{O}(4.4-4.9 \%$, average $=4.6$ $\%$, Fo82-92), similar to or slightly lower within error compared to common mantle olivine (4.8-5.5 $\%$; Mattey et al., 1994). Olivines from D-FP sample AL/B9-03 exhibit slightly higher $\delta^{18} \mathrm{O}(4.4-5.2$ $\%$, average $=4.9 \%$, Fo84-90), but still within error compared to those of AL/B7-03 at a given Fo content (Fig. 5a). Sample AL/WM1e-98 olivines show the highest and $\delta^{18} \mathrm{O}(5.2-6.1 \%$, average $=$ $5.6 \%$, Fo83-87) of the D-FP magma type. Interestingly, the olivine having the highest $\delta^{18} \mathrm{O}$ value is the most primitive one in this sample (Fo87). Cumulate sample 5-mk-91 with the most evolved olivines of the D-FP group exhibits low olivine $\delta^{18} \mathrm{O}(4.5-4.9 \%$, average $=4.7 \%$, Fo78-81).

The olivines from the CFB lavas exhibit considerably higher $\delta^{18} \mathrm{O}$ compared to D-FP olivines in general: there is within-error overlap with only three of the AL/WM1e-98 olivines. The $\delta^{18} \mathrm{O}$ of the different CT magma type olivines are very similar to each other (low- $\varepsilon_{\mathrm{Nd}}$ CT1 sample AL/307: 6.3-7.0 \%o, average $=6.6 \%$, Fo80-88; CT3 sample sk221-AVL: 6.2-7.5\% 75; CT3 sample sk229-AVL: $6.6-6.9 \%$, average $=6.7 \%$, all are Fo79). The majority of the values are within-error to the high values reported for the olivines of the Tuli and Mwenezi picrites (Fig. 4a; Harris et al., 2015).

It is important to note that the olivines in the most altered sample sk221-AVL gave similar results compared to clearly fresh magmatic olivines from sample sk229-AVL representing the same CT3 magma type, although the one anomalously high value $(6.90 \pm 0.38 \%)$ in the former may have been affected by low-T hydrothermal alteration after emplacement (see, e.g., Bindeman, 2009). Despite this one outlier possibly affected by secondary processes, the homogeneous within-error $\delta^{18} \mathrm{O}$ values of the different CT lavas are evidence of magmatic values recorded by the olivine phenocrysts at the time of their crystallization. 
Heinonen, J.S., Luttinen, A.V., Whitehouse, M.J., 2018. Enrichment of ${ }^{18} \mathrm{O}$ in the mantle sources of the Antarctic portion of the Karoo large igneous province. Contributions to Mineralogy and Petrology 173:21. https://doi.org/10.1007/s00410-018-1447-4 (Author's postprint)

Table 1 Oxygen isotope and mineral chemistry of olivine phenocrysts from the Vestfjella CFBs and related intrusive rocks.

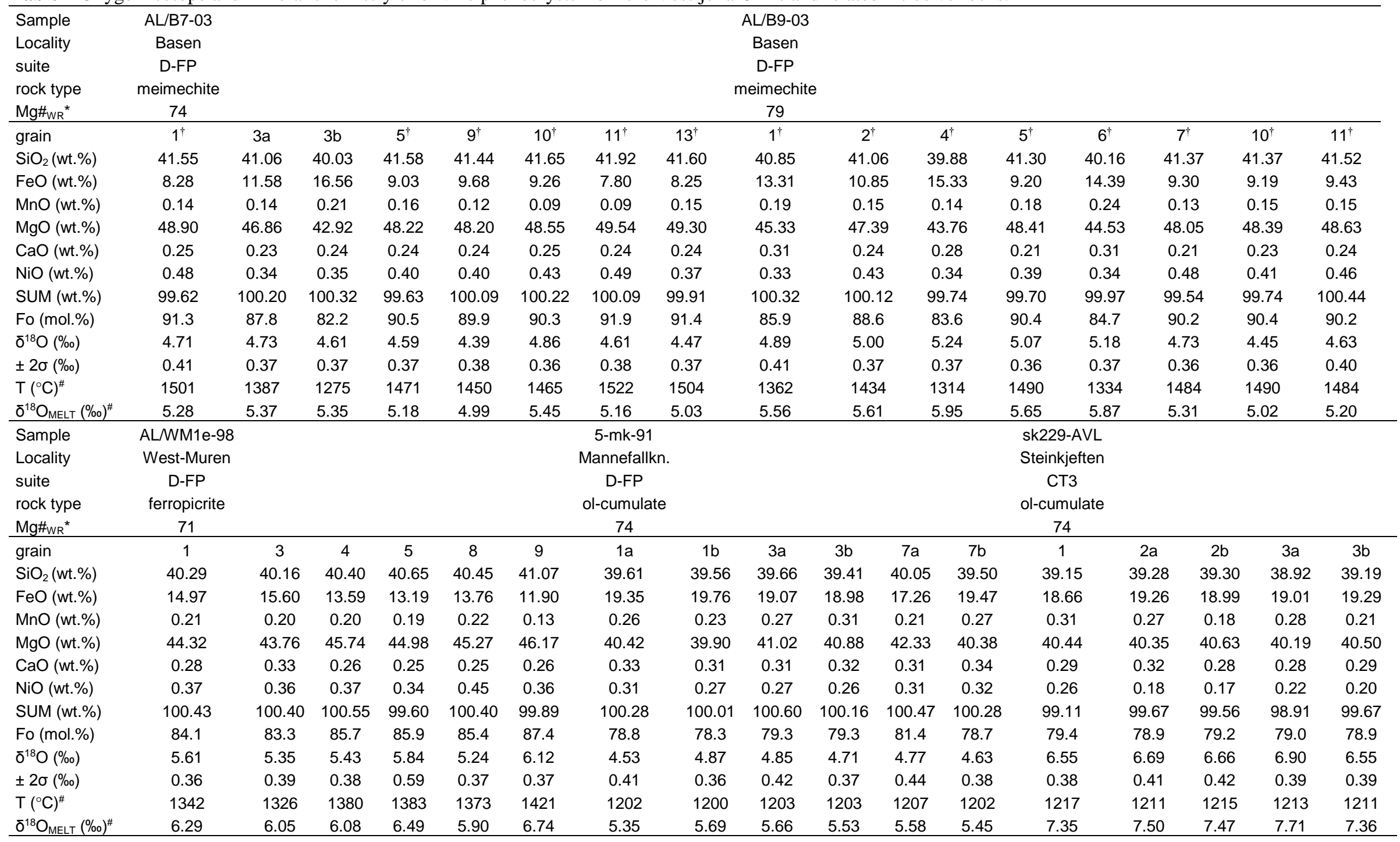


Heinonen, J.S., Luttinen, A.V., Whitehouse, M.J., 2018. Enrichment of ${ }^{18} \mathrm{O}$ in the mantle sources of the Antarctic portion of the Karoo large igneous province. Contributions to Mineralogy and Petrology 173:21. https://doi.org/10.1007/s00410-018-1447-4 (Author's postprint)

\begin{tabular}{|c|c|c|c|c|c|c|c|c|c|c|c|c|c|c|c|c|c|c|c|c|}
\hline Sample & sk221-AVL & & & & & & & & & AL/307 & & & & & & & & & & \\
\hline Locality & Steinkjeften & & & & & & & & & Plogen & & & & & & & & & & \\
\hline suite & СT3 & & & & & & & & & low- $\varepsilon_{N d}$ CT1 & & & & & & & & & & \\
\hline rock type & ol-cumulate & & & & & & & & & ol-cumulate & & & & & & & & & & \\
\hline $\mathrm{Mg}_{\mathrm{WR}}{ }^{*}$ & 74 & & & & & & & & & 81 & & & & & & & & & & \\
\hline grain & 4 & 5 & $7 a$ & $7 \mathrm{~b}$ & 18 & 19 & $23 a$ & $23 b$ & 27 & 1 & 2 & 3 & 4 & 5 & 6 & 7 & 8 & 9 & 10 & 11 \\
\hline $\mathrm{SiO}_{2}$ (wt.\%) & 37.66 & 37.82 & 38.16 & 38.13 & 37.75 & 37.82 & 37.76 & 37.53 & 38.57 & 39.57 & 39.79 & 39.50 & 39.92 & 39.81 & 39.61 & 39.45 & 40.55 & 39.92 & 39.39 & 39.52 \\
\hline $\mathrm{FeO}$ (wt.\%) & 24.89 & 25.65 & 23.32 & 23.50 & 24.40 & 25.54 & 25.39 & 26.72 & 22.26 & 16.85 & 15.44 & 16.62 & 14.51 & 15.68 & 15.21 & 17.62 & 11.57 & 15.45 & 18.17 & 18.19 \\
\hline $\mathrm{MnO}$ (wt.\%) & 0.33 & 0.37 & 0.36 & 0.35 & 0.32 & 0.45 & 0.34 & 0.36 & 0.35 & 0.20 & 0.17 & 0.29 & 0.21 & 0.25 & 0.22 & 0.24 & 0.17 & 0.23 & 0.23 & 0.22 \\
\hline $\mathrm{MgO}$ (wt.\%) & 36.35 & 36.18 & 37.16 & 37.54 & 36.25 & 35.81 & 35.94 & 34.87 & 38.05 & 42.30 & 43.45 & 42.60 & 44.03 & 43.49 & 43.08 & 41.47 & 46.29 & 43.19 & 41.10 & 40.82 \\
\hline $\mathrm{CaO}$ (wt.\%) & 0.27 & 0.30 & 0.26 & 0.28 & 0.28 & 0.29 & 0.20 & 0.28 & 0.31 & 0.23 & 0.25 & 0.23 & 0.22 & 0.24 & 0.23 & 0.22 & 0.20 & 0.23 & 0.26 & 0.23 \\
\hline $\mathrm{NiO}$ (wt.\%) & 0.23 & 0.17 & 0.17 & 0.14 & 0.23 & 0.15 & 0.21 & 0.16 & 0.17 & 0.43 & 0.45 & 0.36 & 0.34 & 0.45 & 0.37 & 0.31 & 0.48 & 0.37 & 0.27 & 0.19 \\
\hline SUM (wt.\%) & 99.73 & 100.49 & 99.43 & 99.93 & 99.23 & 100.07 & 99.85 & 99.91 & 99.71 & 99.58 & 99.55 & 99.60 & 99.21 & 99.92 & 98.73 & 99.32 & 99.26 & 99.40 & 99.43 & 99.17 \\
\hline Fo (mol.\%) & 72.3 & 71.6 & 74.0 & 74.0 & 72.6 & 71.4 & 71.6 & 69.9 & 75.3 & 81.7 & 83.4 & 82.0 & 84.4 & 83.2 & 83.5 & 80.8 & 87.7 & 83.3 & 80.1 & 80.0 \\
\hline$\delta^{18} \mathrm{O}(\% 0)$ & 6.16 & 6.21 & 6.77 & 6.85 & 6.38 & 6.48 & 6.98 & 6.81 & 7.51 & 6.37 & 6.98 & 6.40 & 6.66 & 6.79 & 6.77 & 6.84 & 6.26 & 6.61 & 6.84 & 6.34 \\
\hline $\pm 2 \sigma(\% \circ)$ & 0.36 & 0.36 & 0.39 & 0.41 & 0.37 & 0.37 & 0.49 & 0.36 & 0.38 & 0.41 & 0.36 & 0.37 & 0.39 & 0.39 & 0.39 & 0.39 & 0.37 & 0.39 & 0.40 & 0.36 \\
\hline $\mathrm{T}\left({ }^{\circ} \mathrm{C}\right)^{\#}$ & 1170 & 1171 & 1177 & 1177 & 1171 & 1171 & 1171 & 1171 & 1181 & 1258 & 1285 & 1264 & 1301 & 1281 & 1286 & 1243 & 1353 & 1283 & 1233 & 1231 \\
\hline$\delta^{18} \mathrm{O}_{\text {MELT }}(\% \circ)^{\#}$ & 7.02 & 7.06 & 7.61 & 7.69 & 7.23 & 7.33 & 7.83 & 7.67 & 8.36 & 7.13 & 7.71 & 7.15 & 7.38 & 7.52 & 7.50 & 7.61 & 6.93 & 7.35 & 7.63 & 7.13 \\
\hline
\end{tabular}

${ }^{\dagger}$ Mineral oxide chemistry published in Heinonen and Fusswinkel (in press); ${ }^{*} \mathrm{Mg \#}$ calculated from the whole-rock composition assuming Fe ${ }^{2+} / \mathrm{Fe}^{\text {tot }}=0.9$ (Heinonen and Luttinen, 2008; Heinonen et al., 2010); \# For the calculation of crystallization temperature of olivine and $\delta^{18} \mathrm{O}_{\text {MELT }}$, see section 5. 

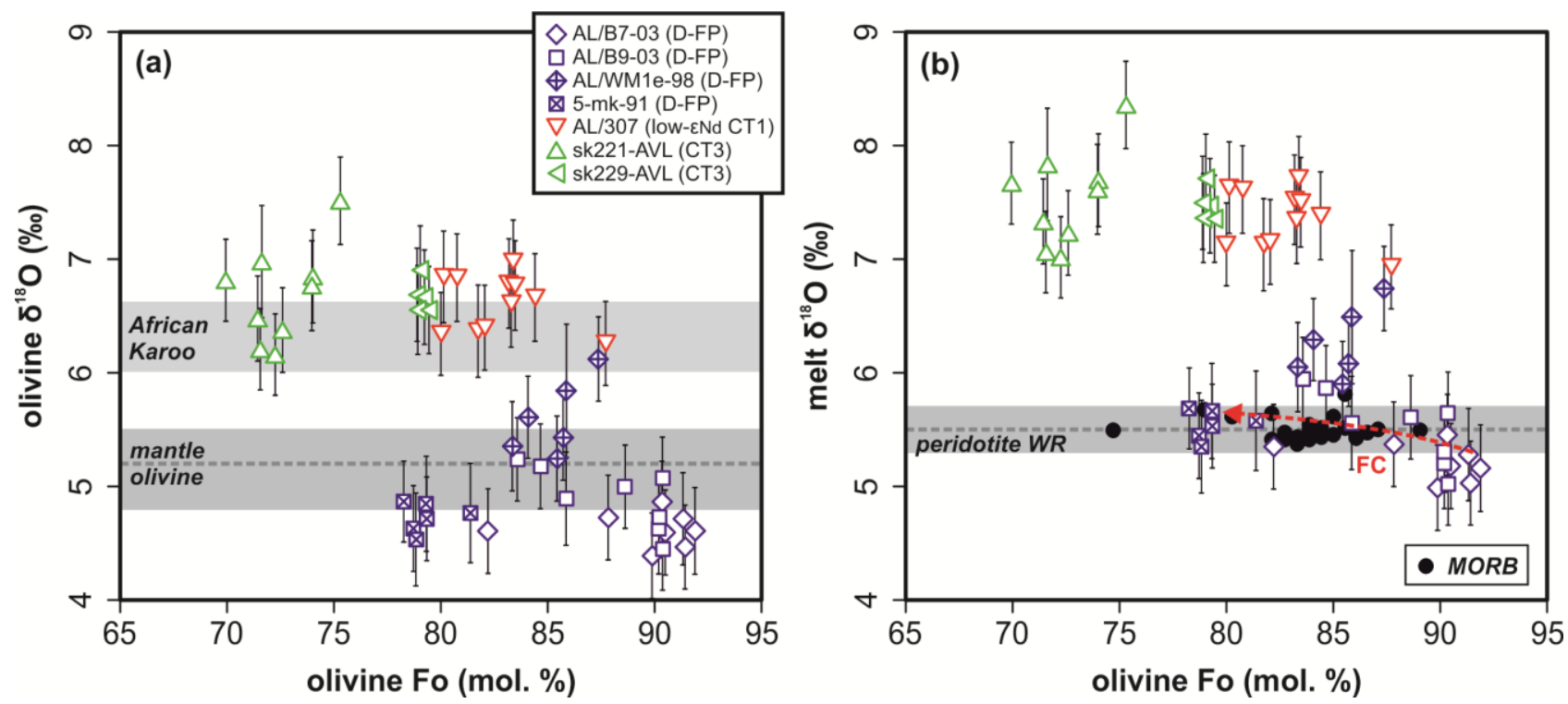

Fig. 4. Oxygen isotopic compositions of a) the analyzed Vestfjella olivines and b) equilibrium melts shown relative to olivine Fo content, error bars are $\pm 2 \sigma$ (Table 1). In a, $\delta^{18} \mathrm{O}$ ranges of olivines from Mwenezi and Tuli picrites from Africa are after Harris et al. (2015; Fo not reported) and the $\delta^{18} \mathrm{O}$ ranges of mantle olivine are after Mattey et al. (1994; full range) and Eiler (2001; average). In b, peridotite whole-rocks are after Eiler (2001) (average $\pm 1 \sigma)$ and references therein. MORB data is based on analyses of MORB glasses from Pacific, Atlantic, and Indian Oceans (Eiler et al., 2000); Fo content of equilibrium olivine has been calculated assuming $\mathrm{Fe}^{2+} / \mathrm{Fe}^{\text {tot }}$ of 0.9 and $\mathrm{K}_{\mathrm{d}}\left(\mathrm{Fe}^{2+}-\mathrm{Mg}\right)^{\mathrm{ol}-\mathrm{liq}}$ of 0.30 . Fractional crystallization model (FC) is explained in section 6.

\section{Oxygen isotopic composition of the parental magmas}

The oxygen isotopic composition of olivine does not directly reflect that of the melt from which it crystallized (see, e.g., Eiler, 2001). We calculated the melt $\delta^{18} \mathrm{O}$ in equilibrium with each olivine analysis by utilizing the equation $10^{3} \ln \alpha_{\text {olivine-basalt }}=\mathrm{A} \times 10^{6} / \mathrm{T}^{2}$, in which $\mathrm{T}$ is olivine crystallization temperature and $\mathrm{A}$ is -1.77 , which was calculated for olivine in equilibrium with a normalized basaltic melt composition (Zhao and Zheng, 2003). Possible variations in factor A in high temperatures and $\mathrm{MgO}$-rich compositions represented by our samples have a negligible effect on the fractionation of $\delta^{18} \mathrm{O}$ (see Eiler, 2001).

Melt compositions for the estimation of olivine crystallization temperature were calculated for melt-representative D-FP samples AL/B7-03 and AL/B9-03 by adding or subtracting equilibrium olivine in $0.5 \mathrm{wt}$ \% steps until the resulting compositions were in equilibrium with the Fo content of each analyzed olivine. Similar approach was also used for AL/WM1e-98 after a slight correction for minor olivine accumulation (subtraction of average olivine until in equilibrium with the wholerock composition). In the case of D-FP sample 5-mk-91 that represents a cumulate from a basaltic magma, a representative basaltic sample of the same magma type (P27-AVL; Luttinen and Furnes, 2000) was used as a starting melt composition. In the case of the CT lava samples that are altered cumulates, the composition of the melt in equilibrium with each analyzed olivine was estimated on the basis of averaged whole-rock trends of fresh low- $\varepsilon_{\mathrm{Nd}} \mathrm{CT} 1$ and CT3 lavas. $\left(\mathrm{Fe}^{2+} / \mathrm{Fe}^{\mathrm{tot}}\right)^{\mathrm{liq}}$ and $\mathrm{K}_{\mathrm{d}}\left(\mathrm{Fe}^{2+}-\mathrm{Mg}\right)^{\mathrm{ol}-\mathrm{liq}}$ were estimated to be 0.9 and 0.35 in all cases, respectively (see Heinonen and Luttinen, 2008, 2010). The olivine crystallization temperatures for the resulting melt compositions were then determined with PELE software (Boudreau, 1999) at $5 \mathrm{kbar}$ and assuming $\mathrm{H}_{2} \mathrm{O}^{\text {liq }}$ content of 0.5 wt.\% in the case of CT samples and D-FP sample 5-mk-91 and at $10 \mathrm{kbar}$ and assuming $\mathrm{H}_{2} \mathrm{O}^{\text {liq }}$ content of $1 \mathrm{wt} . \%$ in the case of other D-FP samples (see Heinonen and Luttinen, 2008, 2010: Heinonen et al., 2010). We note that an error of $100{ }^{\circ} \mathrm{C}$ in the crystallization temperature results in maximum $\delta^{18} \mathrm{O}$ error of $0.13 \%$ in the melt compositions, which is well within the precision of the measurements in olivine. 
The calculated olivine crystallization temperatures and melt $\delta^{18} \mathrm{O}$ values are presented in Table 1 and the latter illustrated in Fig. 4b. The calculated melt $\delta^{18} \mathrm{O}$ values for the normal D-FP samples are similar to those of mantle peridotite whole-rocks and MORB glasses. The melt $\delta^{18} \mathrm{O}$ does not seem to clearly correlate with initial whole-rock $\mathrm{Sr}, \mathrm{Nd}$, and $\mathrm{Pb}$ radiogenic isotope compositions (only initial ${ }^{206} \mathrm{~Pb} /{ }^{204} \mathrm{~Pb}$ ratio shows a slight negative correlation) of the studied rocks and magma types in general (Fig. 5a,b,d-f). Instead, a strong correlation can be found relative to ${ }^{187}$ Os $/{ }^{188}$ Os (Fig. 5c).
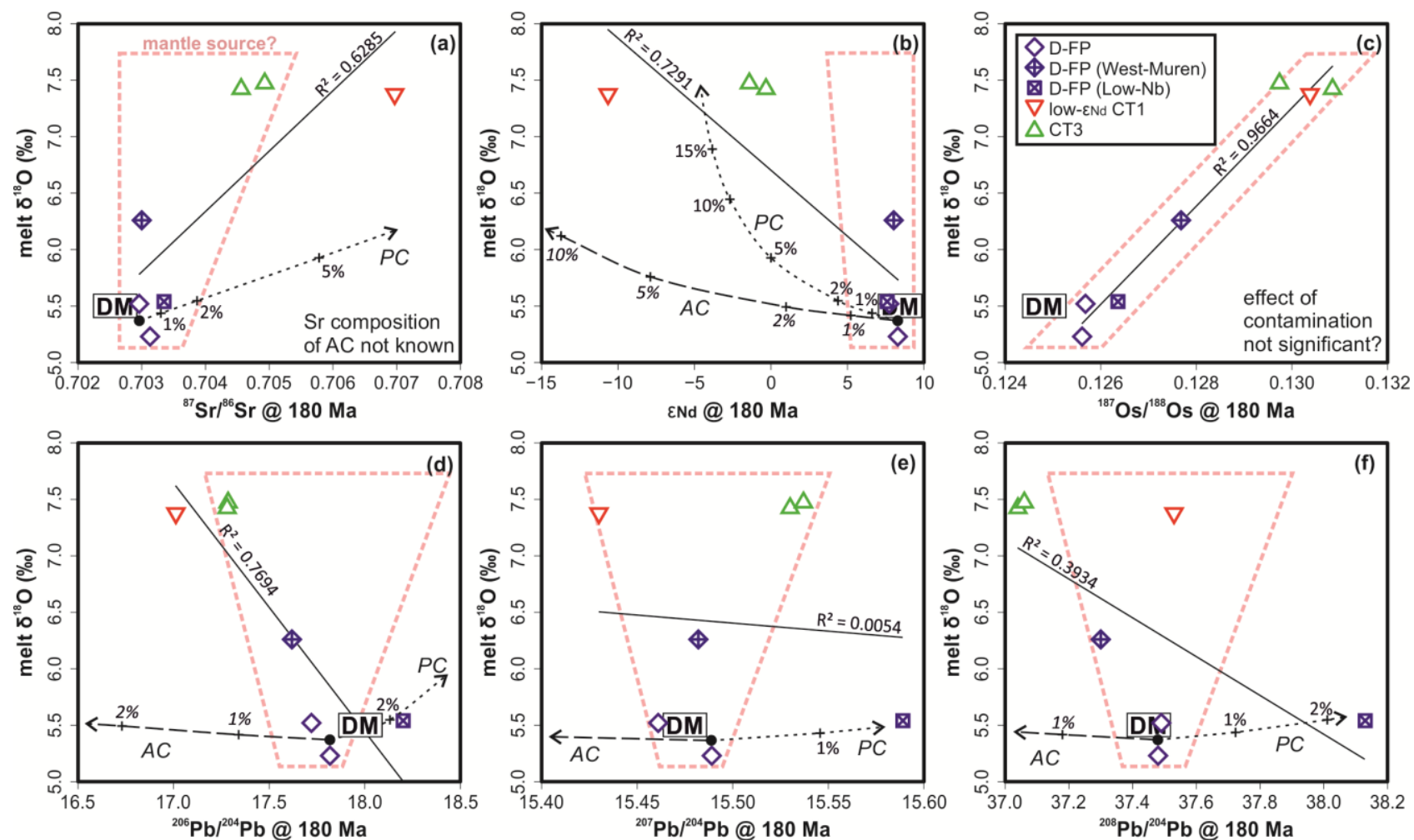

Fig. 5. Average sample-specific melt $\delta^{18} \mathrm{O}$ values of the Vestfjella samples shown relative to a) $\left.{ }^{87} \mathrm{Sr} /{ }^{86} \mathrm{Sr}, \mathrm{b}\right){ }^{\left.\varepsilon_{\mathrm{Nd}}, \mathrm{c}\right)}$ ${ }^{187} \mathrm{Os} /{ }^{188} \mathrm{Os}$, d) ${ }^{206} \mathrm{~Pb} /{ }^{204} \mathrm{~Pb}$, e) ${ }^{207} \mathrm{~Pb} /{ }^{204} \mathrm{~Pb}$, and f) ${ }^{208} \mathrm{~Pb} /{ }^{204} \mathrm{~Pb}$ at $180 \mathrm{Ma}$. Sources for the radiogenic isotope data are Heinonen and Luttinen (2008) and Heinonen et al. (2010). Trend line of all data is shown with square of correlation value $\left(\mathrm{R}^{2}\right)$. The $\mathrm{O}$ isotopic composition of the depleted MORB mantle (DM) is after Eiler (2001). The $\mathrm{Sr}, \mathrm{Nd}, \mathrm{and} \mathrm{Pb}$ isotope composition of DM at $180 \mathrm{Ma}$ calculated using present-day compositions and parent-daughter ratios reported by Workman and Hart (2005), except present-day ${ }^{208} \mathrm{~Pb} /{ }^{204} \mathrm{~Pb}$ composition after Hart (1988). The Os isotopic composition of DM at $180 \mathrm{Ma}$ calculated using present-day ${ }^{187} \mathrm{Os} /{ }^{188} \mathrm{Os}$ and ${ }^{187} \mathrm{Re} /{ }^{188} \mathrm{Os}$ reported by Shirey and Walker (1998). Continuous depletion of the DM source not taken into account as it does not have a notable effect on the isotopic compositions in these timescales. Energy-constrained assimilation-fractional crystallization models (Bohrson and Spera, 2001) with Archean (AC) and Proteorozoic (PC) crust are shown for all isotopes except for Os (model parameters for this element, e.g., in terms of the local crust are poorly constrained). Tick marks indicate the mass of assimilated material relative to the mass of the original magma. The model parameters are as in Heinonen et al. (2010) with the following additions and exceptions: $\delta^{18} \mathrm{O}$ of the parental magma is $5.37 \%$ (average of AL/B7-03 and AL/B9-03 olivines; Table 1), $\delta^{18} \mathrm{O}$ of AC is $10 \%$ (Johnstone, 2001), $\delta^{18} \mathrm{O}$ of $\mathrm{PC}$ is $12 \%$ (Johnstone and Harris, 2001), and isobaric specific heat and crystallization enthalpy of the parental magma is after Heinonen et al. (2016). The anomalous $\mathrm{Pb}$ isotopic composition of the Low-Nb D-FP sample 5-mk-91 is likely due to minor in-situ assimilation of the adjacent Proterozoic granite (Heinonen et al., 2010). The pink quadrangles represent hypothetical compositional range of the metasomatized but otherwise depleted mantle source - estimating this range for $\mathrm{Pb}$ isotopes is difficult, because all the involved parent and daughter elements ( $\mathrm{U}, \mathrm{Th}$, and $\mathrm{Pb}$ ) may be variably mobile in subduction environments (e.g., Kogiso et al., 1997). 
Heinonen, J.S., Luttinen, A.V., Whitehouse, M.J., 2018. Enrichment of ${ }^{18} \mathrm{O}$ in the mantle sources of the Antarctic portion of the Karoo large igneous province. Contributions to Mineralogy and Petrology 173:21. https://doi.org/10.1007/s00410-018-1447-4 (Author's postprint)

\section{The effect of fractional crystallization on $\delta^{18} \mathrm{O}$}

We have modeled the effect of fractional crystallization of olivine on melt $\delta^{18} \mathrm{O}$ using the equation $\Delta=1000\left(\mathrm{f}^{\alpha-1}-1\right)$, in which $\Delta$ is the change in the $\delta^{18} \mathrm{O}$ value, $\mathrm{f}$ is the fraction of remaining melt, and $\alpha$ is mineral-melt oxygen isotope fractionation factor. The latter is slightly affected by decreasing temperature in a fractionating magma; we simplified this effect by using constant $\alpha_{\text {olivine- }}$ basalt of 0.9993 which is a representative average value for MgO-rich magmas crystallizing in temperature range of $\sim 1500-1200{ }^{\circ} \mathrm{C}$ (see Zhao and Zheng, 2003). Including pyroxene and An-rich plagioclase in the modeling would make the effect of fractionation less significant as both minerals

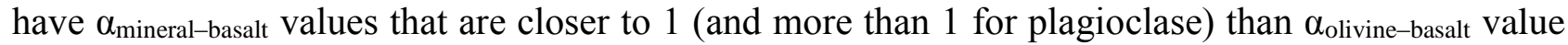
(Zhao and Zheng, 2003). Therefore, our model can be considered to illustrate the maximum effect of crystal fractionation. Starting composition was a melt-representative D-FP sample AL/B9-03 in equilibrium with $\mathrm{Fo}_{92}$ olivine and having $\delta^{18} \mathrm{O}$ of $5.3 \%$, $\mathrm{Fe}^{2+} / \mathrm{Fe}^{\text {tot }}$ of 0.9 , and $\mathrm{K}_{\mathrm{d}}\left(\mathrm{Fe}^{2+}-\mathrm{Mg}\right)^{\mathrm{ol}-\mathrm{liq}}$ of 0.35 (see Heinonen and Luttinen, 2010).

It is evident from our fractional crystallization model that such a process cannot explain the relative ${ }^{18} \mathrm{O}$ enrichment of the Vestfjella CT lavas and the West-Muren D-FP sample (Fig. 4b). The fact that the most Mg-rich olivines of the West-Muren sample exhibit the highest $\delta^{18} \mathrm{O}$ is intriguing. This is also the only sample, in which the olivines exhibit reverse zoning in terms of Fo content, a feature that has been attributed to magma mixing (Heinonen and Luttinen, 2008). The $\mathrm{O}$ isotopic data hints to mixing between an evolved "normal" D-FP magma and relatively more primitive ${ }^{18} \mathrm{O}$ enriched magma in the case of this dike.

\section{The effect of crustal assimilation on $\delta^{18} O$}

Most D-FP samples do not show any trace element or radiogenic isotope $(\mathrm{Sr}, \mathrm{Nd}$, or $\mathrm{Pb})$ evidence of crustal assimilation (Heinonen et al., 2010). This observation alone precludes crustal assimilation as the cause of the high $\delta^{18} \mathrm{O}$ in the otherwise isotopically depleted West-Muren D-FP sample and connects the $\mathrm{O}$ isotopic variation within this magma type to its mantle sources.

The case with the uniformly ${ }^{18} \mathrm{O}$-enriched Vestfjella CT lavas is more complicated, as they show evidence of interaction with lithospheric materials either in the source or in large crustal magma chambers before eruption (Luttinen et al., 1998; Luttinen and Furnes, 2000; Heinonen et al., 2016). Unlike fractional crystallization, large-scale crustal assimilation can result in significant changes in magma $\delta^{18} \mathrm{O}$ value (e.g., Baker et al., 2000). This effect depends on the degree of assimilation, as well as on the relative difference in the $\delta^{18} \mathrm{O}$ composition of the magma and assimilated material.

Several lines of evidence indicate that the relatively high $\delta^{18} \mathrm{O}$ values shown by the Vestfjella CT lavas are not dominantly caused by crustal assimilation: 1) $\delta^{18} \mathrm{O}$ does not correlate with $\mathrm{Sr}, \mathrm{Nd}$, and $\mathrm{Pb}$ radiogenic isotope compositions (Fig. 5). 2) The Vestfjella samples do not plot close to crustal assimilation trends in $\delta^{18} \mathrm{O}$ vs. radiogenic isotope plots (Fig. 5). Lead is highly enriched in continental crust and just small amount of crustal assimilation would shift the $\mathrm{Pb}$ isotopic composition towards that of the crustal assimilant (Fig. 5d-f). On the other hand, the $\mathrm{Pb}$ isotopic signature of continental crust is highly variable and it is possible that the potential crustal assimilants had $\mathrm{Pb}$ isotopic composition similar to that of the hypothetical parental melt. We emphasize that we used the highest $\delta^{18} \mathrm{O}$ values known from the common rock types of the local basement and that the selected Archean assimilant represents the best-fit assimilant composition on the basis of 16 trace elements and $\mathrm{Nd}$ isotopes for the low- $\varepsilon_{\mathrm{Nd}} \mathrm{CT} 1$ lavas (Heinonen et al., 2016). 3) The CT lavas show uniform $\delta^{18} \mathrm{O}$ within Fo range of 70-88 mol. \%. In contrast, negative correlation of Fo vs. $\delta^{18} \mathrm{O}$ would be expected in the case of progressive crustal assimilation (Fig. 4). 4) Trace element and radiogenic isotope modeling indicates that low- $\varepsilon_{\mathrm{Nd}} \mathrm{CT} 1$ magmas assimilated Archean 
Heinonen, J.S., Luttinen, A.V., Whitehouse, M.J., 2018. Enrichment of ${ }^{18} \mathrm{O}$ in the mantle sources of the Antarctic portion of the Karoo large igneous province. Contributions to Mineralogy and Petrology 173:21. https://doi.org/10.1007/s00410-018-1447-4 (Author's postprint)

crust whereas CT3 magmas did not assimilate crust at all, but originated in part from SCLM sources (Luttinen and Furnes, 2000; Luttinen et al., 2015; Heinonen et al., 2016). Yet, both of these magma types show uniformly elevated $\delta^{18} \mathrm{O}$ values that are similar to the highest values shown by the WestMuren D-FP sample (Fig. 4). 5) Local Archean granitoids record whole-rock $\delta^{18} \mathrm{O}$ values of $10 \%$ (Johnstone, 2001). Energy-constrained assimilation-fractional crystallization models (see Fig. 5 for details) indicate that $40 \mathrm{wt} . \%$ of assimilation of such crustal rocks would be required to achieve the magmatic $\delta^{18} \mathrm{O}$ values of the low- $\varepsilon_{\mathrm{Nd}} \mathrm{CT} 1$ lavas, assuming an initial common-mantle-like $\delta^{18} \mathrm{O}$ value of $\sim 5.4 \%$ for the parental magma. Such high amounts are not thermodynamically feasible and the resulting considerably Si-enriched compositions would not be picrites or high-Mg basalts anymore (see Heinonen et al., 2016).

On the basis of the evidence presented above, we propose that the ${ }^{18} \mathrm{O}$-enriched signal of the Vestfjella CT lavas is not the result of crustal assimilation, but derives from their mantle sources. This mantle-derived ${ }^{18} \mathrm{O}$-enriched signal has been recorded by the most $\mathrm{Mg}$-rich olivines of the LILE-enriched West-Muren D-FP dike that likely shared the same ultimate asthenospheric mantle sources with the CFB lavas (see Heinonen et al., 2016).

\section{Reason for the ${ }^{18} \mathrm{O}$ enrichment in the mantle sources of the Vestfjella CFBs}

Mantle-derived high $\delta^{18} \mathrm{O}$ of the West-Muren D-FP dike and CT lavas requires the incorporation of near-surface materials in their mantle sources: the most probable candidates are 1) recycled crust and 2) subduction-related fluids.

\subsection{Recycled crust in the source?}

Hydrothermally altered oceanic upper crust and overlying sediments may exhibit $\delta^{18} \mathrm{O}$ values up to $20 \%$ and $40 \%$, respectively (Gregory and Taylor, 1981; Eiler, 2001), and elevated $\delta^{18} \mathrm{O}$ in primitive volcanic rocks has been linked to entrainment of recycled crustal materials in their mantle sources (e.g., Woodhead et al., 1993; Workman et al., 2008; Harris et al., 2015). In fact, Eiler et al. (2000) linked the correlation of relatively high $\delta^{18} \mathrm{O}$ with elevated $\mathrm{K}$ and $\mathrm{Ba}$ contents in MORBs to entrainment of up to $7 \mathrm{wt}$ \% of subducted upper oceanic crustal materials. Recycled crust may be present in the mantle as separate bodies of eclogite/pyroxenite or as a geochemical component in refertilized peridotite.

Potential indicators of recycled pyroxenitic sources are olivine Ni (Sobolev et al., 2005) and whole-rock $\mathrm{Zn} / \mathrm{Fe}$ (Le Roux et al., 2010), $\mathrm{MgO} / \mathrm{CaO}$ (Herzberg and Asimow, 2008), and FC3MS $\left(\mathrm{FeO}{ }^{\text {tot }} / \mathrm{CaO}-3 \times \mathrm{MgO} / \mathrm{SiO}_{2}\right.$; Yang and $\left.\mathrm{Zhou}, 2013\right)$. First three of these may also be affected by refertilized peridotite sources (Yang et al., 2016). Furthermore, e.g., temperatures and pressures of melting and crystallization have been shown to have a considerable effect on Ni partitioning in olivine (Li and Ripley, 2010; Matzen et al., 2013). For a thorough review on the different pyroxenite source indicators, the reader is referred to Yang et al. (2016). Importantly, the rocks studied here belong to the same portion of the Karoo LIP and it can be assumed that they have originated under fairly similar mantle conditions beneath thick continental lithosphere. Therefore, the information given by the aforementioned source indicators here may be more meaningful than, e.g., in the case of global comparison of within-plate basalts (see Yang and Zhou, 2013, Howarth and Harris, 2017).

If recycled pyroxenite sources are the explanation for the ${ }^{18} \mathrm{O}$-enrichment in the Vestfjella CFBs, positive correlations of $\delta^{18} \mathrm{O}$ with other pyroxenite source indicators would be expected. Such correlations have been identified in a recent study on Paraná-Etendeka and African Karoo LIP picrites (Howarth and Harris, 2017). It is evident from Fig. 6a that there are no significant differences in olivine Ni within the analyzed samples at a given olivine Fo. The D-FP and CT3 samples show similar $\mathrm{Zn} / \mathrm{Fe}$ that is close to that of a hypothetical peridotite melt (Fig. 6b). A couple 
of low- $\varepsilon_{\mathrm{Nd}} \mathrm{CT} 1$ samples show slightly elevated $\mathrm{Zn} / \mathrm{Fe}$, but this may also be due to them being olivine cumulates from more evolved magmas (see Le Roux et al., 2010). Most of the primitive DFP and CT3 samples show similar $\mathrm{MgO} / \mathrm{CaO}$ and plot in or close to the "peridotite partial melt" field in the diagram (Fig. 6c). More differentiated samples show evidence of fractionation of clinopyroxene and plagioclase and distinction between peridotite vs. pyroxenite sources cannot be made in this respect (see Herzberg and Asimow, 2008). Furthermore, the composition of some of the $\mathrm{MgO}$-rich low- $\varepsilon_{\mathrm{Nd}} \mathrm{CT} 1$ samples may be influenced by accumulation of olivine from more evolved magmas and/or assimilation of $\mathrm{CaO}$-poor Archean crustal materials (see Heinonen et al., 2016). One of the CT3 samples also plots in the field of excessively MgO-rich pyroxenite melt compositions; we do not consider it further, but speculate that it may be caused by olivine accumulation from more evolved magmas or depletion of $\mathrm{Ca}$ due to secondary alteration. Finally, all of the D-FP samples and most of the Vestfjella CT lavas exhibit FC3MS values below the upper limit of peridotite-derived melts (Fig. 6d). Again, the FC3MS parameter of some of the low- $\varepsilon_{\mathrm{Nd}}$ CT1 samples could have been compromised by assimilation of $\mathrm{SiO}_{2}$-rich and $\mathrm{CaO}$-poor Archean crustal materials.

In summary, although elevated $\delta^{18} \mathrm{O}$ and $\mathrm{K}$ could hypothetically indicate the involvement of recycled pyroxenitic sources for West-Muren D-FP dike and CT lavas, evidence from other pyroxenite source indicators is not convincing (Fig. 6). This is especially important in the case of olivine $\mathrm{Ni}$ that is well-shielded from the effects of crustal assimilation, crystal fractionation, accumulation, and secondary alteration which may have compromised the other pyroxenite-source parameters, especially in the case of the CT lavas. The presented geochemical evidence indicates relatively similar peridotite-dominated mantle sources for the Vestfjella D-FP and CT magma types (see also Heinonen et al., 2016). It is also important to note that the apparent Fe- and Ti-enrichment of D-FP is not the result of pyroxenite sources, but of generation of the highly magnesian parental melts at low degrees of melting (resulting in high $\mathrm{Ti}$ and high $\mathrm{Fe}$ ) of dominantly peridotitic mantle at high pressures (resulting in even higher $\mathrm{Fe}$ and low $\mathrm{Al}$ ) beneath the cratonic Gondwanan lithosphere; this aspect has been extensively discussed elsewhere (Heinonen and Luttinen 2010; Heinonen et al., 2010; Heinonen and Kurz, 2015; Heinonen and Fusswinkel, 2017; see also Walter, 1998). The possibility of peridotite sources refertilized by recycled crust is more difficult to evaluate, however, although many of the aforementioned pyroxenite indicators overlap with results from refertilized peridotite experiments (Yang et al., 2016). Regardless of whether traces of recycled components were present in the mantle source in a form or another, there is considerable evidence of the involvement of fluids in the sources of the ${ }^{18} \mathrm{O}$-enriched samples as will be discussed in the following section. 

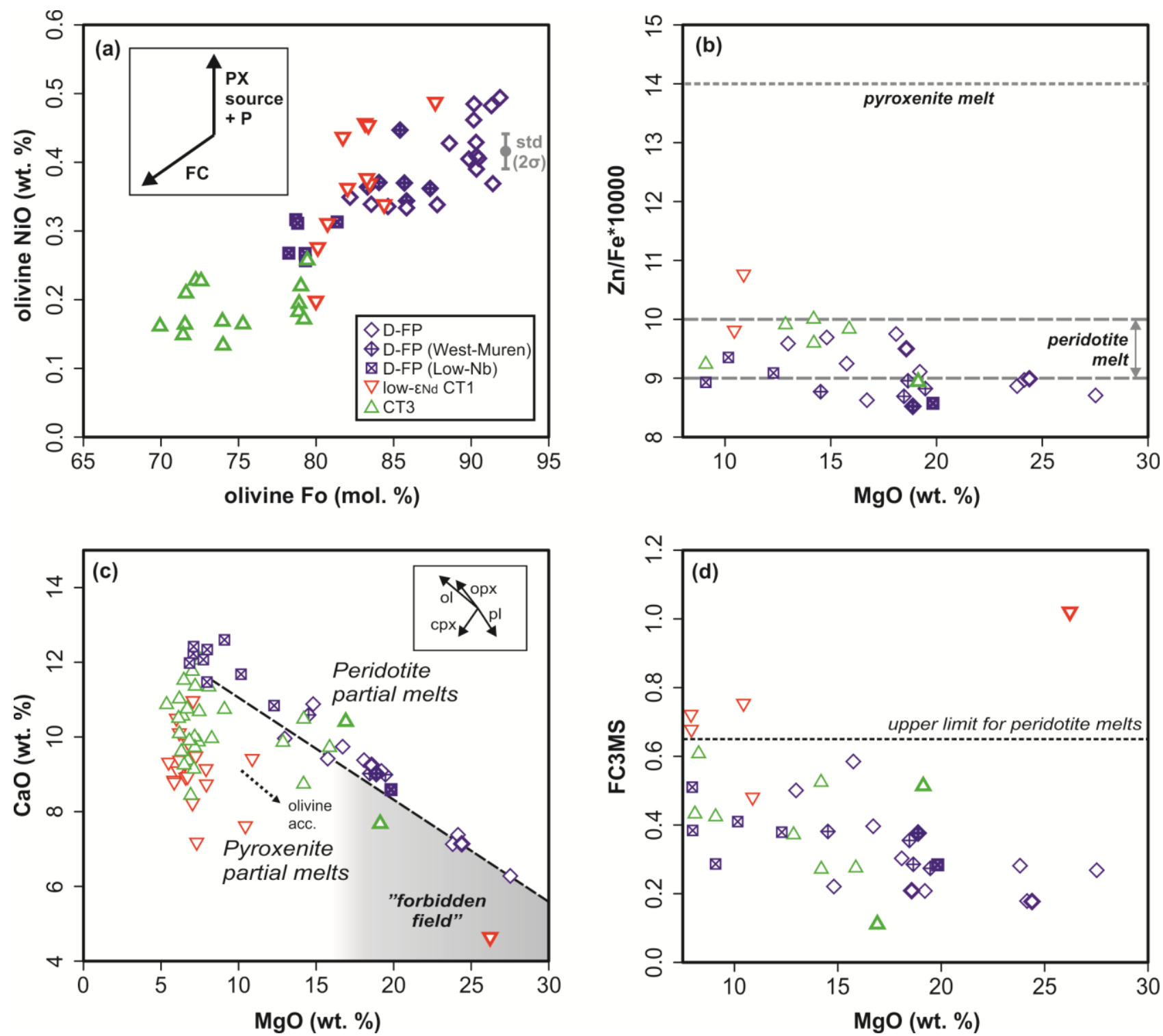

Fig. 6. The compositions of the Vesftjella samples shown in diagrams that illustrate different pyroxenite source indicators: a) olivine $\mathrm{Ni}$ and b) whole-rock $\mathrm{Zn} / \mathrm{Fe}$, c) $\mathrm{MgO} / \mathrm{CaO}$, and d) $\mathrm{FC} 3 \mathrm{MS}\left(\mathrm{FeO}^{\text {tot }} / \mathrm{CaO}-3^{*} \mathrm{MgO}_{\mathrm{SiO}}\right)$. Data sources for the Vestfjella samples as in Fig. 5. Zn/Fe and FC3MS only shown for samples having $\mathrm{MgO}$ in excess of 8.5 and 7.5 wt. \%, respectively (see Le Roux et al., 2010; Yang and Zhou, 2013; Zn data missing for CT1 sample AL/307). Samples analyzed for $\mathrm{O}$ isotopes in this study highlighted with bold symbols as in Fig. 3. In a, average of repeated olivine standard analysis and $2 \sigma$ in terms of $\mathrm{NiO}$ (Heinonen and Fusswinkel, 2017) and approximate effects of fractional crystallization (FC) and pyroxenite source and pressure (PX source + P) (see Sobolev et al., 2007; Li and Ripley, 2010; Matzen et al., 2013) are shown. In b, peridotite melt (peridotite melt 1) and pyroxenite melt are after Le Roux et al. (2010). In c, hypothetical peridotite and pyroxenite partial melt fields after Herzberg and Asimow (2008); "forbidden field" indicates pyroxenite partial melt compositions that are excessively $\mathrm{Mg}$-rich and have rarely been produced experimentally. Notice the effect of fractionation of clinopyroxene (cpx) and plagioclase (pl) over olivine (ol) and orthopyroxene (opx) in the more evolved samples: fractionation of these minerals eventually shifts more evolved magmas in the pyroxenite melt field regardless of their primary $\mathrm{CaO} / \mathrm{MgO}$. In d, upper limit for peridotite melts is after Yang and Zhou (2013).

\subsection{Metasomatism of the source?}

High $\delta^{18} \mathrm{O}$ signal of the upper oceanic crust can also be released from the subducting slab to the overlying mantle by metasomatic processes (e.g., Eiler et al., 1998; Liu et al., 2014). Although it is likely that most of such activity takes place in arc environments at relatively shallow depths, 
Heinonen, J.S., Luttinen, A.V., Whitehouse, M.J., 2018. Enrichment of ${ }^{18} \mathrm{O}$ in the mantle sources of the Antarctic portion of the Karoo large igneous province. Contributions to Mineralogy and Petrology 173:21. https://doi.org/10.1007/s00410-018-1447-4 (Author's postprint)

some fluids or fluid-rich low-degree melts may be released as deep as mantle transition zone (e.g., Maruyama and Okamoto, 2007; Dixon et al., 2017) or even in the lower mantle (Palot et al., 2016).

Numerous crystallized melt inclusions in the D-FP olivines contain primary kaersutite that indicates water contents of $\sim 1-2$ wt. $\%$ in the parental magmas and enrichment of water in their mantle sources (Heinonen and Luttinen, 2010). The inclusions in the West-Muren D-FP olivines contain more kaersutite on average (34-51 vol.\%) than those in other D-FP samples (7-24 vol.\%). Although melt inclusions have not been mapped in detail in CT lavas, it is worth nothing that higher degree of melting in the hydrous DM source relative to all D-FP magmas (Heinonen et al., 2016) could result in relatively lower water content in their parental melts.

Fluid-rich mantle metasomatism would result in the formation of hydrous phases, e.g., phlogopite and/or K-richterite at the base of the continental lithosphere (Sudo and Tatsumi, 1990; Konzett and Ulmer, 1999). Figure 7 illustrates the effect of adding 5 wt.\% of phlogopite or Krichterite component into a normal $-\delta^{18} \mathrm{O}$ D-FP magma in terms of incompatible trace elements. Such addition is broadly analogous to these components being consumed by partial melting in the mantle source. Mineral major and trace element compositions have been acquired from micaamphibole-rutile-ilmenite-diopside (MARID) xenoliths that derive from the base of the Kaapvaal SCLM (Grégoire et al., 2002). Addition of phlogopite causes major enrichment of $\mathrm{K}, \mathrm{Rb}$, and $\mathrm{Ba}$ (Fig. 7a), whereas addition of K-richterite causes major enrichment of $\mathrm{K}$ and minor enrichment of $\mathrm{Rb}$ and $\mathrm{Sr}$ (Fig. 7b). Addition (i.e. contribution to the primary melt) of these minerals to a normal$\delta^{18} \mathrm{O}$ D-FP magma results in strikingly similar trace element pattern to that of the West-Muren D-FP dike and implies that melts from mica- and/or amphibole-bearing sources were involved in its petrogenesis. It is important to note that the kaersutite-bearing melt inclusions indicate the presence of water also in the sources of normal $-\delta^{18} \mathrm{O}$ D-FP melts and their trace element patterns indicate minor enrichment in $\mathrm{Rb}$ (Fig. 3f). This could imply that their sources contained only minor amounts of mica/amphibole or possibly some other high-P $\mathrm{H}_{2} \mathrm{O}$-bearing phases, e.g., garnet that can store up to 0.1 wt. $\%$ of water at mantle conditions (Mookherjee and Karato, 2010).

Assuming that $5 \mathrm{wt} \%$ addition of a metasomatic component to a normal- $\delta^{18} \mathrm{O}$ D-FP magma explains the trace element signature of the West-Muren D-FP dike (Fig. 7), this component would have to have $\delta^{18} \mathrm{O}$ of ca. $20 \%$ to explain the change in $\delta^{18} \mathrm{O}$ from $\sim 5.5 \%$ (normal D-FP melt) to $\sim 6.3 \%$ (average West-Muren melt). Although this is a simplification of how the actual process involving complex fluid-rock interaction may have taken place, it nevertheless gives broad constraints for the $\mathrm{O}$ isotopic composition of the metasomatic component. If associated with subduction of oceanic crust, such high values are only found in its sedimentary portions (clastic sediments, pelagic clays, carbonates, or opaline oozes; 10-40 \%; Gregory and Taylor, 1981; Eiler, 2001). Importantly, recent studies have suggested that at mantle depths of 180-280 km below subduction zones, supercritical $\mathrm{C}-\mathrm{O}-\mathrm{H}-\mathrm{Cl}$ fluids derived from carbonated sediments dominate the volatile budget (Dixon et al., 2017). In addition, super-hydrated clay minerals may be able to carry significant amounts of water to similar or even greater depths (Hwang et al., 2017). Fluids from these kinds of high- $\delta^{18} \mathrm{O}$ sources in subducted crust could have metasomatized parts of the mantle below or in the lower parts of the Gondwanan lithosphere.

Similar calculations and comparisons are much more difficult to make for the CT lavas because their geochemistry has been affected by more significant interaction with lithospheric materials (Heinonen et al., 2016). More ${ }^{18} \mathrm{O}$-enriched or larger amounts of fluid-enriched mantle components would nevertheless be needed to explain their high mantle-derived $\delta^{18} \mathrm{O}$ solely by metasomatic fluids (Fig. 4b). Importantly, Os isotopic compositions are not easily modified by crustal assimilation, because crustal rock types usually have very low Os concentrations (e.g., Carlson, 2005). Furthermore, Re may be very mobile in subduction-related metasomatic fluids (Dale et al., 2007) resulting in time-progressive increase in ${ }^{187} \mathrm{Os} /{ }^{188} \mathrm{Os}$ in the metasomatized source, which is compatible with the correlation of initial ${ }^{187} \mathrm{Os} /{ }^{188} \mathrm{Os}$ with $\delta^{18} \mathrm{O}$ (Fig. 5c). The Vestfjella lavas are also characterized by significant relative enrichment in $\mathrm{K}$ as well as $\mathrm{Rb}, \mathrm{Ba}$ and $\mathrm{Sr}$ (Fig. 
3d,e). If the enrichment in these LILEs is a completely mantle-derived feature (see Luttinen and Furnes, 2000), more complex metasomatic processes than suggested for the source of the WestMuren D-FP dike would be required. In any case, the primary high $\delta^{18} \mathrm{O}$ of the lavas indicates recycling of surface $\mathrm{O}$ to the mantle, which together with the enrichment in fluid-mobile LILEs and ${ }^{187} \mathrm{Os} /{ }^{188} \mathrm{Os}$ can be reasonably attributed to subduction-related metasomatic processes in the mantle source.
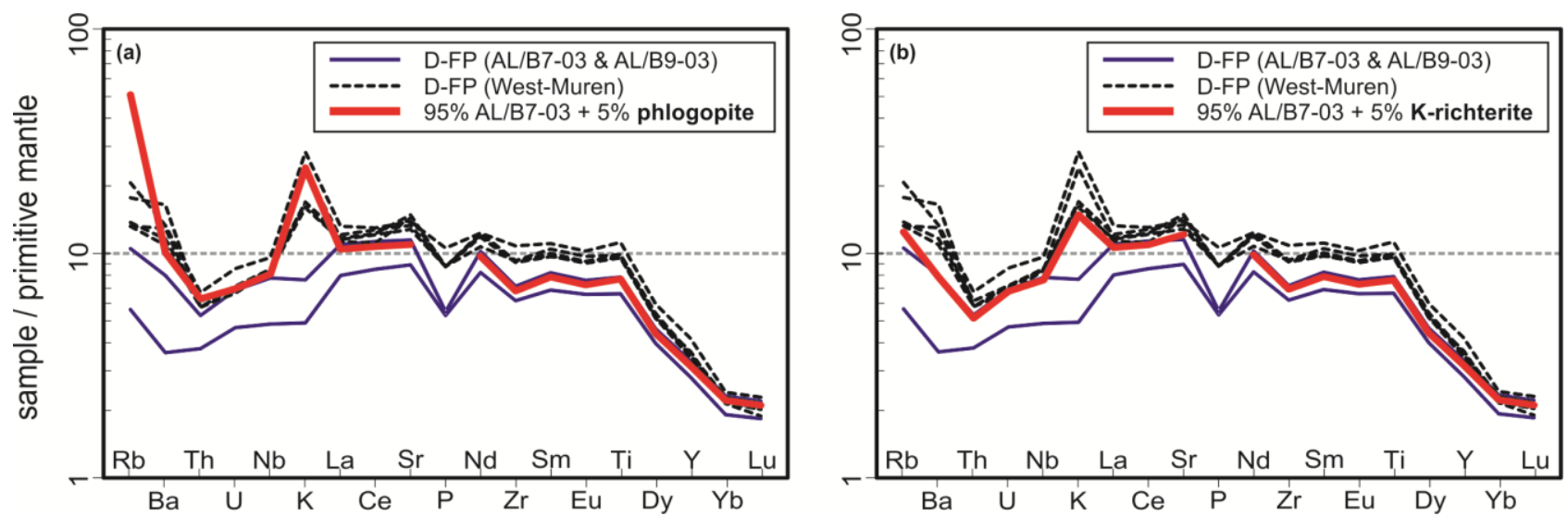

Fig. 7. Mixing models of normal D-FP magma (sample AL/B7-03 with trace element concentrations comparable to those of the West-Muren dike) and a) phlogopite or b) K-richterite shown in primitive-mantle-normalized trace element patterns. Normalization values after Sun and McDonough (1989). Trace element data of the D-FP samples from Heinonen and Luttinen (2008). Trace element compositions for phlogopite and K-richterite that were used as mixing components are averages of respective minerals from the MARID xenoliths reported by Grégoire et al. (2002; P data not available).

\section{Implications}

Although we cannot preclude the involvement of recycled crustal rocks (especially in the form of refertilized peridotite), we suggest that the predominant cause for the ${ }^{18} \mathrm{O}$-enrichment in the olivines of the West-Muren D-FP dike and the Vestfjella CT lavas is mantle metasomatism related to the release of fluids from subducting slabs (Fig. 8). It is important to note that the proposed ancient eclogite-derived origin for the high $\delta^{18} \mathrm{O}$ observed in Karoo LIP picrites of southern Africa (Harris et al., 2015; Howarth and Harris, 2017) is not in discordance with our interpretations. The Mwenezi picrites have been shown to exhibit very strong affinity to SCLM (e.g., Hawkesworth et al., 1984; Ellam and Cox, 1989, 1991; Ellam, 2006; Jourdan et al., 2007) and have sampled different sources relative to dominantly sublithospheric Vestfjella magmas (Luttinen et al., 2015; Heinonen et al., 2016). Alternatively, the high $\delta^{18} \mathrm{O}$ of the Mwenezi picrites could also derive from the possible asthenospheric depleted end-member source (see Ellam and Cox, 1991; Kamenetsky et al., 2017) shared by the D-FP and Vestfjella CFBs. The overall influence of these high- $\delta^{18} \mathrm{O}$ sources, whether they are recycled eclogites or metasomatized peridotites, on Karoo magmatism as a whole is difficult to constrain. This is because extensive $\mathrm{O}$ isotopic data for Karoo LIP, especially in the case of widespread and voluminous plateau lavas and sills (e.g., Neumann et al., 2011), is lacking and magmatic compositions have often been overprinted by assimilation of lithospheric materials (this possibility should individually be evaluated for each suite). Nevertheless, such source rocks are much more fertile than dry peridotitic sources and would have a large potential to increase melt productivity and heterogeneity in the mantle. Wang et al. (2016) suggested high weighted mean water contents of $1.92 \pm 0.12 \mathrm{wt} . \%$ for the parental magmas of Karoo LIP on the basis of phase equilibria and fluid-mobile trace element ratios, which is also compatible with general relative water enrichment in the mantle sources of the Karoo LIP. 


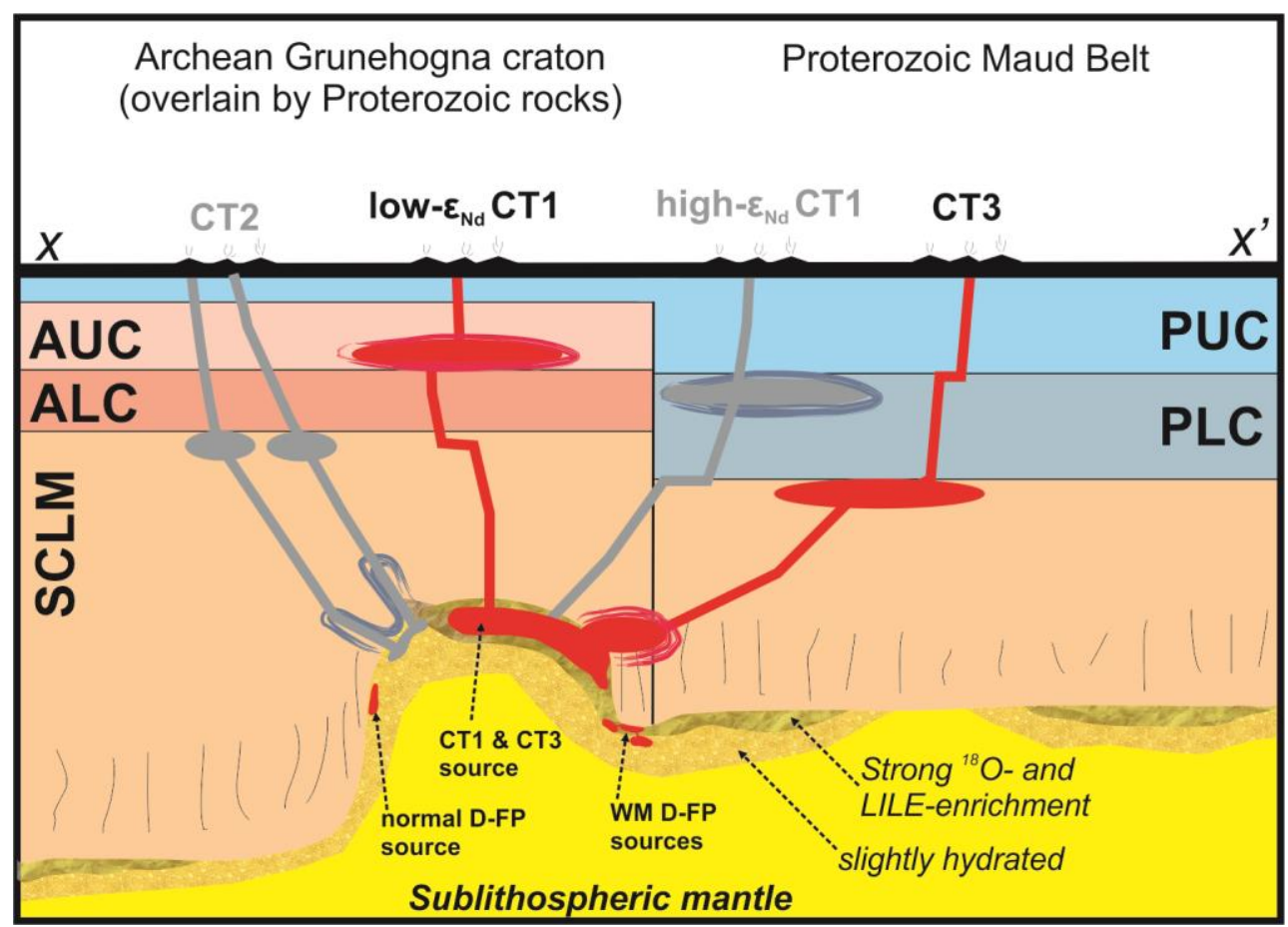

Fig. 8. A schematic cross section across line segment $x-x^{\prime}$ (Fig. 2) during Karoo CFB magmatism showing the primary magma sources for the CT lavas, West-Muren D-FP, and normal D-FP magmas. Models for assimilation implemented from Heinonen et al. (2016) and implications from the LILE enrichment (high- $\varepsilon_{\mathrm{Nd}}$ CT1) or lack thereof (CT2) taken into account (see Luttinen and Furnes, 2000). Plumbing systems for D-FP magmas not shown in order to preserve clarity they did not significantly fractionate in crustal magma chambers or assimilate lithospheric materials. AUC $=$ Archean upper crust; ALC = Archean lower crust; PUC = Proterozoic upper crust; PLC = Proterozoic lower crust; SCLM = Subcontinental lithospheric mantle with metasomatized (veined) portions.

The $\mathrm{Sr}, \mathrm{Nd}, \mathrm{Pb}$, Os, and $\mathrm{He}$ isotopic signatures of the D-FP dikes (including the West-Muren dike) strongly suggest long-term depleted sublithospheric sources for them. Specifically, the depleted radiogenic isotope character of the West-Muren dike indicates that the metasomatic process that resulted in the enrichment of $\delta^{18} \mathrm{O}$ and $\mathrm{K}$ must have been relatively recent. One of the small differences of the D-FP radiogenic isotope signature relative to those of DM and SWIR MORBs are the relatively higher initial ${ }^{87} \mathrm{Sr} /{ }^{86} \mathrm{Sr}$ of the former (Heinonen et al., 2010). We suggest this to be the consequence of the $\mathrm{Rb}$-enrichment in the source that has also resulted in the relative enrichment of $\mathrm{Rb}$ in the trace element patterns of all of the D-FP samples (Fig. 3f,g). If the Rb- and water-enrichment in the sources of the normal- $\delta^{18} \mathrm{O}$ D-FP samples is a faint reflection of the same metasomatic process that caused the enrichment in $\mathrm{K}$ (+ other LILE), ${ }^{187} \mathrm{Os}$, and $\delta^{18} \mathrm{O}$ in the WestMuren D-FP dike and CT lavas, we can estimate the timing of this process with the help of simple $\mathrm{Rb}-\mathrm{Sr}$ isotope modeling. Figure 9 illustrates the $\mathrm{Sr}$ isotopic evolution of the depleted MORB mantle (DMM) and of the source of the D-FP samples AL/B9-03 and AL/WM1e-98 that show the lowest ${ }^{87} \mathrm{Sr} /{ }^{86} \mathrm{Sr}$ of the analyzed D-FP samples and have preserved the $\mathrm{Rb} / \mathrm{Sr}$ of the primary magmas (see Heinonen and Luttinen, 2008, 2010). Depending on the degree of melting in the source required to produce such a melt (3-12\%; Heinonen and Luttinen, 2010), the source diverged from the DMM evolution line and experienced $\mathrm{Rb}$-enrichment no earlier than $750 \mathrm{Ma}$ ago. Although the presented model is certainly a simplification, this lower limit is similar to what has been proposed for the age of the recycled and subduction-modified oceanic crustal component in the pyroxenitic sources of the Group 3 picrites from Ahlmannryggen (younger than $1 \mathrm{Ga}$ and best-fit at $700 \mathrm{Ma}$; Heinonen et al., 2014). During these times, the cratonic cores of Antarctica and Africa were part of the supercontinent Rodinia, below which large quantities of oceanic lithosphere were subducting from several directions (e.g., Murphy et al., 2004). In addition, there are indications of subduction beneath the Kalahari-Grunehogna craton already before Rodinia assembly (Marshcall et al., 2013). 
Whether the proposed metasomatism of the sub-Gondwanan mantle took place at the base of the lithosphere or in the deeper parts of the mantle is not readily answered by our data. However, Wang et al. (2015) linked the wet transition zone signal not to high but to low $\delta^{18} \mathrm{O}$ values in CFBs, because of supposed release of fluids from lower oceanic crust and ultramafic oceanic lithosphere in the deeper parts of the mantle. Importantly, and despite the elevated water contents, high temperatures are required for the generation of the D-FP magmas, which suggests that either mantle plumes and/or continental insulation processes played an important part in the generation of the Karoo LIP (Heinonen et al., 2015b). This does not in any way preclude the possible involvement of 'wet' transition zone upwellings (Wang et al., 2015) or rapid release of water from subducted slabs (Ivanov et al., 2016), possibly instigated by a mantle plume or some other geodynamic processes, although the age implications listed above are not directly compatible with the latter.

The presented $\mathrm{O}$ isotope data together with other geochemical evidence support the involvement of mantle components variably modified by subduction fluids in the petrogenesis of the Vestfjella CFBs. Given the prevalence of arc-like geochemical signatures in Karoo CFB province and other CFBs in general, such fertile sources may be important factors in the creation of vast amounts of basaltic magma in the asthenospheric mantle below continents (see Wang et al., 2016).

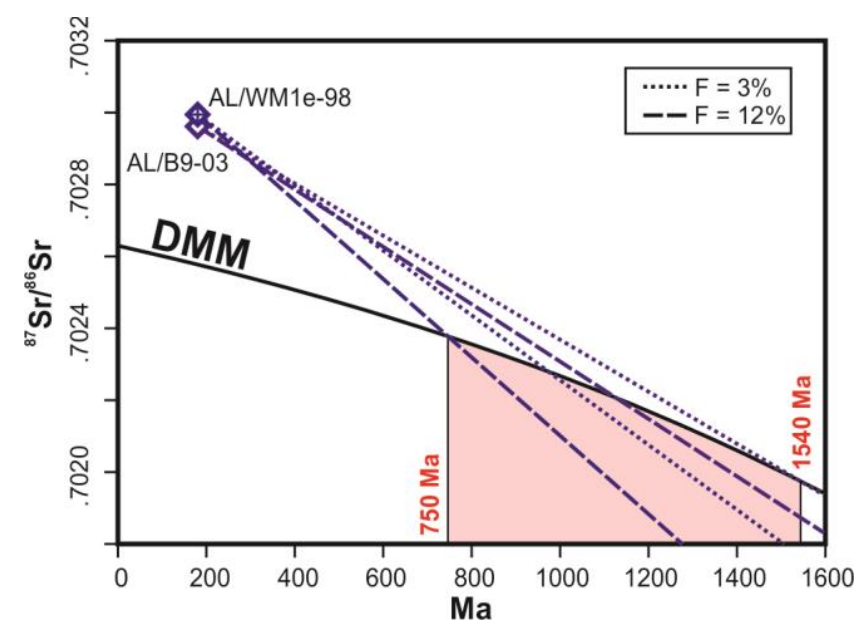

Fig. 9. Temporal Sr isotopic evolution of depleted MORB mantle (DMM) and the hypothetical sources of the D-FP samples AL/WM1e-98 and AL/B9-03. For the partial melting models and for the calculation of ${ }^{87} \mathrm{Rb} /{ }^{86} \mathrm{Sr}$ of the source, degrees of melting of 3-12\% (Heinonen and Luttinen, 2010) and garnet peridotite modes, melt modes, and partition coefficients of Janney et al. (2005) were utilized. DMM trend is after 3 Ga gradual depletion model of Workman and Hart (2005).

\section{Conclusions}

On the basis of olivine oxygen isotopic data for a suite of Jurassic dike rocks (depleted ferropicritic D-FP magma type) and CFBs (low- $\varepsilon_{\mathrm{Nd}} \mathrm{CT} 1$ and CT3 magma types) related to the Karoo LIP, we present the following conclusions:

1. The D-FP magma suite that has previously been affiliated with DM sources shows division into two subgroups on the basis of $\delta^{18} \mathrm{O}$ : olivines from most of the samples exhibit normal mantle-like $\delta^{18} \mathrm{O}$ of $4.4-5.2 \%$ (average $=4.8 \%$, Fo78-92), whereas olivines from a single dike from WestMuren exhibit slightly elevated $\delta^{18} \mathrm{O}$ of 5.2-6.1 \%o (average $=5.6 \%$, Fo83-87). The two groups do not show significant differences in terms of $\mathrm{Sr}, \mathrm{Nd}$, and $\mathrm{Pb}$ radiogenic isotope compositions, but the ${ }^{18} \mathrm{O}$-enriched West-Muren ferropicrite exhibits relatively higher whole-rock ${ }^{187} \mathrm{Os} /{ }^{188} \mathrm{Os}$ and $\mathrm{K}$ contents. All of the LILE- and ${ }^{187}$ Os-enriched flood basalt samples exhibit considerably elevated 
Heinonen, J.S., Luttinen, A.V., Whitehouse, M.J., 2018. Enrichment of ${ }^{18} \mathrm{O}$ in the mantle sources of the Antarctic portion of the Karoo large igneous province. Contributions to Mineralogy and Petrology 173:21. https://doi.org/10.1007/s00410-018-1447-4 (Author's postprint)

$\delta^{18} \mathrm{O}$ in olivine $(6.2-7.5 \%$; average $=6.7 \%$, Fo $70-88)$ regardless of the magma type (low- $\varepsilon_{\mathrm{Nd}} \mathrm{CT} 1$ or CT3).

2. Fractional crystallization cannot explain the relative ${ }^{18} \mathrm{O}$-enrichments in the different magma types, because the variation is too large at a given Fo content.

3. Crustal assimilation cannot explain the relative ${ }^{18} \mathrm{O}$-enrichment of the different magma types: $\delta^{18} \mathrm{O}$ does not correlate with assimilation-sensitive radiogenic isotopes, only low- $\varepsilon_{\mathrm{Nd}} \mathrm{CT} 1$ shows other geochemical evidence of crustal assimilation, and thermodynamically excessive quantities of assimilation would be required.

4. Recycled pyroxenitic or eclogitic source could theoretically explain the elevated $\delta^{18} \mathrm{O}$, but is not supported by other indicators of such sources (olivine $\mathrm{Ni}$ and whole-rock $\mathrm{Zn} / \mathrm{Fe}, \mathrm{MgO} / \mathrm{CaO}$, and FC3MS). The role of peridotite sources refertilized by recycled crustal materials is more difficult to evaluate.

5. The primary cause for the elevated $\delta^{18} \mathrm{O}$, fluid-mobile LILEs, and ${ }^{187} \mathrm{Os}$ in the West-Muren D-FP dike and the CT lavas is likely to be fluid-dominated metasomatism of their mantle sources (base of the lithosphere or deeper) or mixing of the primary magmas with such metasomatized components. Such a scenario is supported by evidence of $\mathrm{H}_{2} \mathrm{O}$-rich mantle sources. The metasomatic components originated from upper portions of subducted (oceanic) lithosphere.

6. Calculations on the basis of $\mathrm{Rb}-\mathrm{Sr}$ isotopes imply that the metasomatic modification took place no earlier than $750 \mathrm{Ma}$ ago, possibly during the time of supercontinent Rodinia. The involvement of such sources would have resulted in higher source heterogeneity and melt production due to increased mantle fertility, but their importance for the petrogenesis of the Karoo LIP as a whole remains to be studied.

\section{Acknowledgements}

We are grateful to two anonymous reviewers and Chris Harris for important commentary that significantly improved the manuscript and to Timothy Grove for editorial handling of the manuscript. Chris Harris also checked the quality of the San Carlos olivine standard used in this study and we are very grateful to him for that. We thank Kerstin Lindén and Lev Ilyinsky for the preparations and assistance related to the SIMS analyses. We also thank Radoslaw Michallik for the guidance with the EPMA analyses at the University of Helsinki. Sanni Turunen is thanked for picking some additional olivine grains for the SIMS analyses. The first author also expresses gratitude to $\mathrm{Aku}$ Heinonen for thought-provoking discussions related to oxygen isotope geochemistry - congratulations for your lectureship position! This is NordSIM contribution number 540. Our research has been funded by the Academy of Finland (Grant No. 252652).

\section{References}

Ahn I, Lee JI, Kusakabe M, Choi B (2012) Oxygen isotope measurements of terrestrial silicates using a $\mathrm{CO}_{2}-\mathrm{laser}_{\mathrm{BrF}}$ fluorination technique and the slope of terrestrial fractionation line. Geosci J 16:7-16. doi:10.1007/s12303-012-0011-x

Baker JA, Macpherson CG, Menzies MA, Thirlwall MF, AL-Kadasi M, Mattey DP (2000) Resolving Crustal and Mantle Contributions to Continental Flood Volcanism, Yemen; Constraints from Mineral Oxygen Isotope Data. J Petrol 41:1805-1820. doi:10.1093/petrology/41.12.1805

Bindeman I (2008) Oxygen Isotopes in Mantle and Crustal Magmas as Revealed by Single Crystal Analysis. Rev Mineral Geochem 69:445-478. doi:10.2138/rmg.2008.69.12 
Heinonen, J.S., Luttinen, A.V., Whitehouse, M.J., 2018. Enrichment of ${ }^{18} \mathrm{O}$ in the mantle sources of the Antarctic portion of the Karoo large igneous province. Contributions to Mineralogy and Petrology 173:21. https://doi.org/10.1007/s00410-018-1447-4 (Author's postprint)

Bohrson WA, Spera FJ (2001) Energy-constrained open-system magmatic processes II: Application of energyconstrained assimilation-fractional crystallization (EC-AFC) model to magmatic systems. J Petrol 42:1019-1041. doi:10.1093/petrology/42.5.1019

Boudreau AE (1999) PELE - a version of the MELTS software program for the PC platform. Comput Geosci 25:201203. doi:10.1016/s0098-3004(98)00117-4

Brandon AD, Hooper PR, Goles GG, Lambert RSJ (1993) Evaluating crustal contamination in continental basalts: the isotopic composition of the Picture Gorge Basalt of the Columbia River Basalt Group. Contrib Mineral Petrol 114:452464. doi:10.1007/BF00321750

Carlson RW (2005) Application of the Pt-Re-Os isotopic systems to mantle geochemistry and geochronology. Lithos 82:249-272. doi:10.1016/j.lithos.2004.08.003

Corner B (1994) Geological evolution of western Dronning Maud Land within a Gondwana framework: Geophysics subprogramme. Final project report to SACAR. Department of Geophysics, Witwaterstrand University, South Africa:21 pp.

Dale CW, Gannoun A, Burton KW, Argles TW, Parkinson IJ (2007) Rhenium-osmium isotope and elemental behaviour during subduction of oceanic crust and the implications for mantle recycling. Earth Planet Sci Lett 253:211225. doi:10.1016/j.eps1.2006.10.029

Dixon JE, Bindeman IN, Kingsley RH, Simons KK, Le Roux PJ, Hajewski TR, Swart P, Langmuir CH, Ryan JG, Walowski KJ, Wada I, Wallace PJ (2017) Light Stable Isotopic Compositions of Enriched Mantle Sources:

Resolving the Dehydration Paradox. Geochem Geophys Geosyst. doi:10.1002/2016GC006743

Duncan AR, Erlank AJ, Marsh JS (1984) Regional geochemistry of the Karoo igneous province. In: Erlank AJ (ed) Petrogenesis of the volcanic rocks of the Karoo Province, Geol Soc S Africa Spec Pub, vol 13, Johannesburg, South Africa, pp 355-388

Eiler JM (2001) Oxygen Isotope Variations of Basaltic Lavas and Upper Mantle Rocks. Rev Mineral Geochem 43:319364. doi:10.2138/gsrmg.43.1.319

Eiler JM, McInnes B, Valley JW, Graham CM, Stolper EM (1998) Oxygen isotope evidence for slab-derived fluids in the sub-arc mantle. Nature 393:777-781. doi:10.1038/31679

Eiler JM, Schiano P, Kitchen N, Stolper EM (2000) Oxygen-isotope evidence for recycled crust in the sources of midocean-ridge basalts. Nature 403:530-534. doi :10.1038/35000553

Ellam RM (2006) New constraints on the petrogenesis of the Nuanetsi picrite basalts from $\mathrm{Pb}$ and Hf isotope data. Earth Planet Sci Lett 245:153-161. doi:10.1016/j.eps1.2006.03.004

Ellam RM, Carlson RW, Shirey SB (1992) Evidence from Re-Os isotopes for plume-lithosphere mixing in Karoo flood basalt genesis. Nature 359:718-721. doi:10.1038/359718a0

Ellam RM, Cox KG (1991) An interpretation of Karoo picrite basalts in terms of interaction between asthenospheric magmas and the mantle lithosphere. Earth Planet Sci Lett 105:330-342. doi:10.1016/0012-821X(91)90141-4

Ellam RM, Cox KG (1989) A Proterozoic lithospheric source for Karoo magmatism: evidence from the Nuanetsi picrites. Earth Planet Sci Lett 92:207-218. doi:10.1016/0012-821X(89)90047-2

Grégoire M, Bell D, Le Roex A (2002) Trace element geochemistry of phlogopite-rich mafic mantle xenoliths: their classification and their relationship to phlogopite-bearing peridotites and kimberlites revisited. Contrib Mineral Petrol 142:603-625. doi:10.1007/s00410-001-0315-8

Gregory RT, Taylor HP (1981) An oxygen isotope profile in a section of Cretaceous oceanic crust, Samail ophiolite, Oman: evidence for $\delta^{18} \mathrm{O}$ buffering of the oceans by deep $(>5 \mathrm{~km})$ seawater-hydrothermal circulation at mid-ocean ridges. J Geophys Res 86:2737-2755. 
Heinonen, J.S., Luttinen, A.V., Whitehouse, M.J., 2018. Enrichment of ${ }^{18} \mathrm{O}$ in the mantle sources of the Antarctic portion of the Karoo large igneous province. Contributions to Mineralogy and Petrology 173:21. https://doi.org/10.1007/s00410-018-1447-4 (Author's postprint)

Groenewald PB, Moyes AB, Grantham GH, Krynauw JR (1995) East Antarctic crustal evolution: geological constraints and modelling in western Dronning Maud Land. Precambrian Res 75:231-250. doi:10.1016/0301-9268(95)80008-6

Hansen H, Nielsen TFD (1999) Crustal contamination in Palaeogene East Greenland flood basalts: plumbing system evolution during continental rifting. Chem Geol 157:89-118. doi:https://doi.org/10.1016/S0009-2541(98)00196-X

Harmon RS, Hoefs J (1995) Oxygen isotope heterogeneity of the mantle deduced from global 180 systematics of basalts from different geotectonic settings. Contrib Mineral Petrol 120:95-114. doi:10.1007/BF00311010

Harris C, le Roux P, Cochrane R, Martin L, Duncan A, Marsh J, le Roex A, Class C (2015) The oxygen isotope composition of Karoo and Etendeka picrites: High $\delta^{18} \mathrm{O}$ mantle or crustal contamination? Contrib Mineral Petrol 170:8. doi:10.1007/s00410-015-1164-1

Hart SR (1988) Heterogeneous mantle domains: signatures, genesis and mixing chronologies. Earth Planet Sci Lett 90:273-296. doi:http://dx.doi.org/10.1016/0012-821X(88)90131-8

Hawkesworth CJ, Marsh JS, Duncan AR, Erlank AJ, Norry MJ (1984) The role of continental lithosphere in the generation of the Karoo volcanic rocks: evidence from combined Nd- and Sr-isotope studies. In: Erlank AJ (ed) Petrogenesis of the volcanic rocks of the Karoo Province, Geol Soc S Africa Spec Pub, vol 13, Johannesburg, South Africa, pp 341-354.

Heinonen JS, Fusswinkel T (2017). High Ni and low Mn/Fe in olivine phenocrysts of the Karoo meimechites do not reflect pyroxenitic mantle sources. Chem Geol. 467:134-142. http://dx.doi.org/10.1016/j.chemgeo.2017.08.002

Heinonen JS, Luttinen AV (2008) Jurassic dikes of Vestfjella, western Dronning Maud Land, Antarctica: Geochemical tracing of ferropicrite sources. Lithos 105:347-364. doi:10.1016/j.lithos.2008.05.010

Heinonen JS, Luttinen AV (2010) Mineral chemical evidence for extremely magnesian subalkaline melts from the Antarctic extension of the Karoo large igneous province. Mineral Petrol 99:201-217. doi:10.1007/s00710-010-0115-9

Heinonen JS, Kurz MD (2015) Low- ${ }^{3} \mathrm{He} /{ }^{4} \mathrm{He}$ sublithospheric mantle source for the most magnesian magmas of the Karoo large igneous province. Earth Planet Sci Lett 426:305-315. doi: 10.1016/j.eps1.2015.06.030

Heinonen JS, Carlson RW, Luttinen AV (2010) Isotopic ( $\mathrm{Sr}, \mathrm{Nd}, \mathrm{Pb}$, and Os) composition of highly magnesian dikes of Vestfjella, western Dronning Maud Land, Antarctica: A key to the origins of the Jurassic Karoo large igneous province? Chem Geol 277:227-244. doi:10.1016/j.chemgeo.2010.08.004

Heinonen JS, Luttinen AV, Riley TR, Michallik RM (2013) Mixed pyroxenite-peridotite sources for mafic and ultramafic dikes from the Antarctic segment of the Karoo continental flood basalt province. Lithos 177:366-380. doi: 10.1016/j.lithos.2013.05.015

Heinonen JS, Carlson RW, Riley TR, Luttinen AV, Horan MF (2014) Subduction-modified oceanic crust mixed with a depleted mantle reservoir in the sources of the Karoo continental flood basalt province. Earth Planet Sci Lett 394:229241. doi:10.1016/j.eps1.2014.03.012

Heinonen A, Andersen T, Rämö OT, Whitehouse M (2015a) The source of Proterozoic anorthosite and rapakivi granite magmatism: evidence from combined in situ $\mathrm{Hf}-\mathrm{O}$ isotopes of zircon in the Ahvenisto complex, southeastern Finland. J Geol Soc London 172:103-112. doi:10.1144/jgs2014-013

Heinonen JS, Jennings ES, Riley TR (2015b) Crystallisation temperatures of the most Mg-rich magmas of the Karoo LIP on the basis of Al-in-olivine thermometry. Chem Geol 411:26-35. doi: 10.1016/j.chemgeo.2015.06.015

Heinonen JS, Luttinen AV, Bohrson WA (2016) Enriched continental flood basalts from depleted mantle melts: modeling the lithospheric contamination of Karoo lavas from Antarctica. Contrib Mineral Petrol 171:9. doi:10.1007/s00410-015-1214-8

Hergt JM, Peate DW, Hawkesworth CJ (1991) The petrogenesis of Mesozoic Gondwana low-Ti flood basalts. Earth Planet Sci Lett 105:134-148. doi:10.1016/0012-821x(91)90126-3 
Heinonen, J.S., Luttinen, A.V., Whitehouse, M.J., 2018. Enrichment of ${ }^{18} \mathrm{O}$ in the mantle sources of the Antarctic portion of the Karoo large igneous province. Contributions to Mineralogy and Petrology 173:21. https://doi.org/10.1007/s00410-018-1447-4 (Author's postprint)

Herzberg C, Asimow PD (2008) Petrology of some oceanic island basalts: PRIMELT2.XLS software for primary magma calculation. Geochem Geophys Geosyst 9. doi:10.1029/2008GC002057

Howarth GH, Harris C (2017) Discriminating between pyroxenite and peridotite sources for continental flood basalts (CFB) in southern Africa using olivine chemistry. Earth Planet Sci Lett 475:143-151. doi:10.1016/j.eps1.2017.07.043

Hwang H, Seoung D, Lee Y, Liu Z, Liermann H, Cynn H, Vogt T, Kao C, Mao H (2017) A role for subducted superhydrated kaolinite in Earth's deep water cycle. Nat Geosci 10:947-953. doi:10.1038/s41561-017-0008-1

Isa J, Kohl IE, Liu M-, Wasson JT, Young ED, McKeegan KD (2017) Quantification of oxygen isotope SIMS matrix effects in olivine samples: Correlation with sputter rate. Chem Geol 458:14-21. doi: 10.1016/j.chemgeo.2017.03.020

Ivanov AV, Meffre S, Thompson J, Corfu F, Kamenetsky VS, Kamenetsky MB, Demonterova EI (2017) Timing and genesis of the Karoo-Ferrar large igneous province: New high precision U-Pb data for Tasmania confirm short duration of the major magmatic pulse. Chem Geol 455:32-43. doi: 10.1016/j.chemgeo.2016.10.008

Jacobs J, Pisarevsky S, Thomas RJ, Becker T (2008) The Kalahari Craton during the assembly and dispersal of Rodinia. Precambrian Res 160:142-158. doi:10.1016/j.precamres.2007.04.022

Jacobs J, Thomas RJ, Weber K (1993) Accretion and indentation tectonics at the southern edge of the Kaapvaal craton during the Kibaran (Grenville) orogeny. Geology 21:203-206. doi:10.1130/00917613(1993)021<0203:AAITAT>2.3.CO;2

Jacobs J, Fanning CM, Henjes-Kunst F, Olesch M, Paech H (1998) Continuation of the Mozambique Belt into East Antarctica: grenville-age metamorphism and polyphase Pan-African highgrade events in central Dronning Maud Land. J Geol 106:385-406. doi:10.1086/516031

Janney PE, le Roex AP, Carlson RW (2005) Hafnium isotope and trace element constraints on the nature of mantle heterogeneity beneath the central Southwest Indian Ridge $\left(13^{\circ} \mathrm{E}\right.$ to $\left.47^{\circ} \mathrm{E}\right)$. J Petrol 46:2427-2464. doi:10.1093/petrology/egi060

Johnstone WP (2001) A stable isotope investigation into fluid-rock interaction during regional metamorphism in Western Dronning Maud Land, East Antarctica. MSc thesis (unpublished), University of Cape Town, 108 pp.

Johnstone WP, Harris C (2001) The effects of early Cambrian metamorphism in western Dronning Maud Land, East Antarctica: a carbon and oxygen isotope study of fluid-rock interaction in the Sverdrupfjella Group. Geol Soc London Spec Pub 184:381-394.doi:10.1144/GSL.SP.2001.184.01.19

Jourdan F, Bertrand H, Schaerer U, Blichert-Toft J, Féraud G, Kampunzu AB (2007) Major and trace element and Sr, $\mathrm{Nd}, \mathrm{Hf}$, and $\mathrm{Pb}$ isotope compositions of the Karoo large igneous province, Botswana-Zimbabwe: lithosphere vs mantle plume contribution. J Petrol 48:1043-1077. doi:10.1093/petrology/egm010

Kamenetsky VS, Maas R, Kamenetsky MB, Yaxley GM, Ehrig K, Zellmer GF, Bindeman IN, Sobolev AV, Kuzmin DV, Ivanov AV, Woodhead J, Schilling J (2017) Multiple mantle sources of continental magmatism: Insights from "high-Ti" picrites of Karoo and other large igneous provinces. Chem Geol 455:22-31. doi: 10.1016/j.chemgeo.2016.08.034

Kogiso T, Tatsumi Y, Nakano S (1997) Trace element transport during dehydration processes in the subducted oceanic crust: 1. Experiments and implications for the origin of ocean island basalts. Earth Planet Sci Lett 148:193-205. doi:10.1016/S0012-821X(97)00018-6

Konzett J, Ulmer P (1999) The Stability of Hydrous Potassic Phases in Lherzolitic Mantle — an Experimental Study to 9.5 GPa in Simplified and Natural Bulk Compositions. J Petrol 40:629-652. doi:10.1093/petroj/40.4.629

Kusakabe M, Matsuhisa Y (2008) Oxygen three-isotope ratios of silicate reference materials determined by direct comparison with VSMOW-oxygen. Geochem J 42:309-317. doi:10.2343/geochemj.42.309

Le Roux V, Lee CA, Turner SJ (2010) Zn/Fe systematics in mafic and ultramafic systems: implications for detecting major element heterogeneities in the Earth's mantle. Geochim Cosmochim Acta 74:2779-2796. doi:10.1016/j.gca.2010.02.004 
Heinonen, J.S., Luttinen, A.V., Whitehouse, M.J., 2018. Enrichment of ${ }^{18} \mathrm{O}$ in the mantle sources of the Antarctic portion of the Karoo large igneous province. Contributions to Mineralogy and Petrology 173:21. https://doi.org/10.1007/s00410-018-1447-4 (Author's postprint)

Leat PT, Luttinen AV, Storey BC, Millar IL (2006) Sills of the Theron Mountains, Antarctica: evidence for long distance transport of mafic magmas during Gondwana break-up. In: Hanski EJ, Mertanen S, Rämö OT, Vuollo J (eds) Dyke Swarms: Time Markers of Crustal Evolution. Taylor \& Francis, Abingdon, pp 183-199.

Li C, Ripley EM (2010) The relative effects of composition and temperature on olivine-liquid Ni partitioning: Statistical deconvolution and implications for petrologic modeling. Chem Geol 275:99-104. doi:10.1016/j.chemgeo.2010.05.001

Lindström S (1995) Early Late Permian palynostratigraphy and palaeo-biogeography of Vestfjella, Dronning Maud Land, Antarctica. Rev Palaeobot Palynol 86:157-173. doi:10.1016/0034-6667(94)00104-R

Liu C, Wu F, Chung S, Li Q, Sun W, Ji W (2014) A 'hidden' ${ }^{18}$ O-enriched reservoir in the sub-arc mantle. Sci Rep $4: 4232$

Luttinen AV, Siivola JU (1997) Geochemical characteristics of Mesozoic lavas and dikes from Vestfjella, Dronning Maud Land: recognition of three distinct chemical types. In: Ricci CA (ed) The Antarctic Region: Geological Evolution and Processes, vol 7. Siena: Terra Antarctica Publications, Italy, pp 495-503.

Luttinen AV, Furnes H (2000) Flood basalts of Vestfjella: Jurassic magmatism across an Archaean-Proterozoic lithospheric boundary in Dronning Maud Land, Antarctica. J Petrol 41:1271-1305. doi:10.1093/petrology/41.8.1271

Luttinen AV, Rämö OT, Huhma H (1998) Neodymium and strontium isotopic and trace element composition of a Mesozoic CFB suite from Dronning Maud Land, Antarctica: Implications for lithosphere and asthenosphere contributions to Karoo magmatism. Geochim Cosmochim Acta 62:2701-2714. doi:10.1016/S0016-7037(98)00184-7

Luttinen AV, Heinonen JS, Kurhila M, Jourdan F, Mänttäri I, Vuori SK, Huhma H (2015) Depleted Mantle-sourced CFB Magmatism in the Jurassic Africa-Antarctica Rift: Petrology and ${ }^{40} \mathrm{Ar} /{ }^{39} \mathrm{Ar}$ and U/Pb Chronology of the Vestfjella Dyke Swarm, Dronning Maud Land, Antarctica. J Petrol 56:919-952. doi:10.1093/petrology/egv022

Marschall HR, Hawkesworth CJ, Storey CD, Dhuime B, Leat PT, Meyer H-, Tamm-Buckle S (2010) The Annandagstoppane Granite, East Antarctica: Evidence for Archaean Intracrustal recycling in the Kaapvaal-Grunehogna Craton from zircon O and Hf isotopes. J Petrol 51:2277-2301. doi:10.1093/petrology/egq057

Marschall HR, Hawkesworth CJ, Leat PT (2013) Mesoproterozoic subduction under the eastern edge of the KalahariGrunehogna Craton preceding Rodinia assembly: The Ritscherflya detrital zircon record, Ahlmannryggen (Dronning Maud Land, Antarctica). Precambrian Res 236:31-45. doi: 10.1016/j.precamres.2013.07.006

Marsh JS (1987) Basalt geochemistry and tectonic discrimination within continental flood basalt provinces. J Volcanol Geotherm Res 32:35-49. doi:10.1016/0377-0273(87)90035-7

Maruyama S, Okamoto K (2007) Water transportation from the subducting slab into the mantle transition zone. Gondwana Res 11:148-165. doi: 10.1016/j.gr.2006.06.001

Mattey D, Lowry D, Macpherson C (1994) Oxygen isotope composition of mantle peridotite. Earth Planet Sci Lett 128:231-241. doi: 10.1016/0012-821X(94)90147-3

Matzen AK, Baker MB, Beckett JR, Stolper EM (2013) The Temperature and Pressure Dependence of Nickel Partitioning between Olivine and Silicate Melt. J Petrol 54:2521-2545. doi:10.1093/petrology/egt055

Mookherjee M, Karato S (2010) Solubility of water in pyrope-rich garnet at high pressures and temperature. Geophys Res Lett 37. doi:10.1029/2009GL041289

Moyes AB, Krynauw JR, Barton JM,Jr (1995) The age of the Ritscherflya Supergroup and Borgmassivet Intrusions, Dronning Maud Land, Antarctica. Antarct Sci 7:87-97. doi:10.1017/S0954102095000125

Murphy JB, Dostal J, Nance RD, Keppie JD (2004) Neoproterozoic juvenile crust development in the peri-Rodinian ocean: Implications for Grenvillian orogenesis. Geol Soc Am Mem 197:135-144. doi:10.1130/0-8137-1197-5.135

Natali C, Beccaluva L, Bianchini G, Siena F (2017) Comparison among Ethiopia-Yemen, Deccan, and Karoo continental flood basalts of central Gondwana: Insights on lithosphere versus asthenosphere contributions in 
Heinonen, J.S., Luttinen, A.V., Whitehouse, M.J., 2018. Enrichment of ${ }^{18} \mathrm{O}$ in the mantle sources of the Antarctic portion of the Karoo large igneous province. Contributions to Mineralogy and Petrology 173:21. https://doi.org/10.1007/s00410-018-1447-4 (Author's postprint)

compositionally zoned magmatic provinces. In: Bianchini G, Bodinier J, Braga R, Wilson M (eds) The Crust-Mantle and Lithosphere-Asthenosphere Boundaries: Insights from Xenoliths, Orogenic Deep Sections, and Geophysical Studies. Geol Soc Am Spec Pap 526:191-215. doi:10.1130/2017.2526(10)

Neumann E, Svensen H, Galerne CY, Planke S (2011) Multistage Evolution of Dolerites in the Karoo Large Igneous Province, Central South Africa. J Petrol 52:959-984. doi:10.1093/petrology/egr011

Palot M, Jacobsen SD, Townsend JP, Nestola F, Marquardt K, Miyajima N, Harris JW, Stachel T, McCammon CA, Pearson DG (2016) Evidence for $\mathrm{H}_{2} \mathrm{O}$-bearing fluids in the lower mantle from diamond inclusion. Lithos 265:237-243. doi: 10.1016/j.lithos.2016.06.023

Peng ZX, Mahoney J, Hooper P, Harris C, Beane J (1994) A role for lower continental crust in flood basalt genesis? Isotopic and incompatible element study of the lower six formations of the western Deccan Traps. Geochmi Cosmochim Acta 58:267-288. doi: 10.1016/0016-7037(94)90464-2

Riley TR, Leat PT, Curtis ML, Millar IL, Duncan RA, Fazel A (2005) Early-Middle Jurassic dolerite dykes from Western Dronning Maud Land (Antarctica): Identifying mantle sources in the Karoo Large Igneous Province. J Petrol 46:1489-1524. doi:10.1093/petrology/egi023

Rudnick RL, Nyblade AA (1999) The thickness and heat production of Archean lithosphere: constraints from xenolith thermobarometry and surface heat flow. In: Fei Y, Bertka CM, Mysen BO (eds) Mantle Petrology: Field Observations and High Pressure Experimentation: A Tribute to Francis R. (Joe) Boyd, Geochem Soc Spec Pub, vol 6, St. Louis, Missouri, US, pp 3-12.

Segev A (2002) Flood basalts, continental breakup and the dispersal of Gondwana: evidence for periodic migration of upwelling mantle flows (plumes). Europ Geosci Union Stephan Mueller Spec Pub Ser 2:171-191. doi: 10.5194/smsps2-171-2002

Shirey SB, Walker RJ (1998) The Re-Os isotope system in cosmochemistry and high-temperature geochemistry. Annu Rev Earth Planet Sci 26:423-500. doi:10.1146/annurev.earth.26.1.423

Simkin T, Smith JV (1970) Minor-element distribution in olivine. J Geol 78:304-325. doi:10.1086/627519

Sobolev AV, Hofmann AW, Kuzmin DV, Yaxley GM, Arndt NT, Chung S, Danyushevsky LV, Elliott T, Frey FA, Garcia MO, Gurenko AA, Kamenetsky VS, Kerr AC, Krivolutskaya NA, Matvienkov VV, Nikogosian IK, Rocholl A, Sigurdsson IA, Sushchevskaya NM, Teklay M (2007) The amount of recycled crust in sources of mantle-derived melts. Science 316:412-417. doi:10.1126/science.1138113

Sobolev AV, Hofmann AW, Sobolev SV, Nikogosian IK (2005) An olivine-free mantle source of Hawaiian shield basalts. Nature 434:590-597. doi:10.1038/nature03411

Starkey NA, Jackson CRM, Greenwood RC, Parman S, Franchi IA, Jackson M, Fitton JG, Stuart FM, Kurz M, Larsen LM (2016) Triple oxygen isotopic composition of the high $-{ }^{3} \mathrm{He} /{ }^{4} \mathrm{He}$ mantle. Geochim Cosmochim Acta 176:227-238. doi:10.1016/j.gca.2015.12.027

Storey BC, Alabaster T, Hole MJ, Pankhurst RJ, Wever HE (1992) Role of subduction-plate boundary forces during the initial stages of Gondwana break-up: evidence from the proto-Pacific margin of Antarctica. In: Storey BC, Alabaster T, Pankhurst RJ (eds) Magmatism and the causes of continental break-up, Geol Soc London Spec Pub, vol 68, London, United Kingdom, pp 149-163. doi: 10.1144/GSL.SP.1992.068.01.10

Sudo A, Tatsumi Y (1990) Phlogopite and K-amphibole in the upper mantle: Implication for magma genesis in subduction zones. Geophys Res Lett 17:29-32. doi:10.1029/GL017i001p00029

Sun SS, McDonough WF (1989) Chemical and isotopic systematics of oceanic basalts: Implications for mantle composition and processes. In: Saunders AD, Norry MJ (eds) Magmatism in the ocean basins, Geol Soc London Spec Pub, vol 42, London, United Kingdom, pp 313-345. doi:10.1144/GSL.SP.1989.042.01.19

Sweeney RJ, Falloon TJ, Green DH, Tatsumi Y (1991) The mantle origins of Karoo picrites. Earth Planet Sci Lett 107:256-271. doi:10.1016/0012-821x(91)90075-s 
Heinonen, J.S., Luttinen, A.V., Whitehouse, M.J., 2018. Enrichment of ${ }^{18} \mathrm{O}$ in the mantle sources of the Antarctic portion of the Karoo large igneous province. Contributions to Mineralogy and Petrology 173:21. https://doi.org/10.1007/s00410-018-1447-4 (Author's postprint)

Thirlwall MF, Gee MAM, Lowry D, Mattey DP, Murton BJ, Taylor RN (2006) Low ${ }^{18} \mathrm{O}$ in the Icelandic mantle and its origins: evidence from Reykjanes Ridge and Icelandic lavas. Geochim Cosmochim Acta 70:993-1019. doi: 10.1016/j.gca.2005.09.008

Walter MJ (1998) Melting of garnet peridotite and the origin of komatiite and depleted lithosphere. J Petrol 39:29-60. doi:10.1093/petroj/39.1.29

Wang X, Wilde SA, Li Q, Yang Y (2015) Continental flood basalts derived from the hydrous mantle transition zone. Nat Commun 6:7700. doi:10.1038/ncomms8700

Wang X, Wilde SA, Xu B, Pang C (2016) Origin of arc-like continental basalts: Implications for deep-Earth fluid cycling and tectonic discrimination. Lithos 261:5-45. doi: 10.1016/j.lithos.2015.12.014

Whithouse MJ, Nemchin AA (2009) High precision, high accuracy measurement of oxygen isotopes in a large lunar zircon by SIMS. Chem Geol 261:32-42. doi:10.1016/j.chemgeo.2008.09.009

Wolmarans LG, Kent KE (1982) Geological investigations in western Dronning Maud Land, Antarctica - a synthesis. S Afr J Antarc Res Suppl., vol 2, 93 p.

Woodhead JD, Greenwood P, Harmon RS, Stoffers P (1993) Oxygen isotope evidence for recycled crust in the source of EM-type ocean island basalts. Nature 362:809-813. doi:10.1038/362809a0

Workman RK, Eiler JM, Hart SR, Jackson MG (2008) Oxygen isotopes in Samoan lavas: Confirmation of continent recycling. Geology 36:551-554. doi:10.1130/G24558A.1

Workman RK, Hart SR (2005) Major and trace element composition of the depleted MORB mantle (DMM). Earth Planet Sci Lett 231:53-72. doi:10.1016/j.epsl.2004.12.005

Yang Z, Li J, Liang W, Luo Z (2016) On the chemical markers of pyroxenite contributions in continental basalts in Eastern China: Implications for source lithology and the origin of basalts. Earth-Sci Rev 157:18-31. doi: 10.1016/j.earscirev.2016.04.001

Yang Z, Zhou J (2013) Can we identify source lithology of basalt? Sci Rep 3:1856. doi:10.1038/srep01856

Yu S, Shen N, Song X, Ripley EM, Li C, Chen L (2017) An integrated chemical and oxygen isotopic study of primitive olivine grains in picrites from the Emeishan Large Igneous Province, SW China: Evidence for oxygen isotope heterogeneity in mantle sources. Geochim Cosmochim Acta 215:263-276. doi:10.1016/j.gca.2017.08.007

Zhao Z, Zheng Y (2003) Calculation of oxygen isotope fractionation in magmatic rocks. Chem Geol 193:59-80. doi: $10.1016 / \mathrm{S} 0009-2541(02) 00226-7$

\section{Online Resources}

Online Resource 1. Olivine fraction photographs in optical microscope $(\mathrm{OM})$ and in scanning electron microscope (SEM).

Online Resource 2. Pristine samples of Vestfjella CFBs and associated dikes

Online Resource 3. Olivine O isotope SIMS data for the samples of this study and San Carlos standard olivine 